\title{
O Sucesso Inesperado das Reformas de Segunda Geração: Federalismo, Reformas Constitucionais e Política Social*
}

\author{
Marcus André Melo
}

\section{INTRODUÇÃO}

$\mathrm{O}$ presente artigo examina os determinantes institucionais e a estrutura do jogo político que permitiram que mudanças profundas no padrão das políticas sociais tenham tido lugar durante a gestão do presidente Fernando Henrique Cardoso (1995-2002). Transformações importantes, com efeito, ocorreram no conjunto das políticas implementadas, e os indicadores de mudança foram expressivos. Esta mudança de padrão ocorreu em vários âmbitos: na reorganização estrutural das relações intergovernamentais no setor, no qual, embora tenha havido continuidade do processo de descentralização setorial, ocorreu um expressivo fortalecimento do controle exercido pelo âmbito federal; no processo orçamentário setorial que se tornou marcadamente "rígido", com amplo e significativo crescimento de despesas "vinculadas" na área social; e no aggionarmento da área social que perdeu inegavelmente vários traços clientelistas pretéritos, e onde ocor-

\footnotetext{
* Artigo apresentado no congresso da Latin American Studies Association - LASA, Las Vegas, 5-7 de outubro de 2004. Agradeço os comentários de James Manor, Joan Nelson, Aaron Schneider, Maria Hermínia Tavares de Almeida, Njuguna Ngethe, Celina Souza, Flávio Rezende e Sônia Draibe. O artigo baseia-se em uma pesquisa comparativa realizada com James Manor e Njuguna Ngethe sobre a política social na Índia, Brasil e em Uganda. [A tradução do original em inglês "The Unexpected Success of Second Generation Reforms: Federalism, Constitutional Reforms and Social Policy“ é de Saulo Souza.]
}

DADOS - Revista de Ciências Sociais, Rio de Janeiro, Vol. 48, n²4, 2005, pp. 845 a 889. 
reu certo insulamento político do setor - ou pelo menos uma reorganização do papel dos ministérios sociais na estratégia de coalizão do governo e uma "periferização" dos espaços burocráticos onde a patronagem política era exercida. Tais mudanças provocaram uma melhoria inequívoca de alguns indicadores sociais, mas a mudança estrutural subjacente tem sido pouco discutida na literatura ${ }^{1}$. Com efeito, alguns programas e iniciativas - o Bolsa Escola, o Fundo de Desenvolvimento do Ensino Fundamental e Valorização do Magistério - Fundef, e o Fundo de Combate à Pobreza - adquiriram notoriedade internacional. A magnitude dos investimentos realizados no período também é expres$s i v a^{2}$. O financiamento partiu de um fundo de pobreza que contou, em 2002 , com mais de $\mathrm{R} \$ 2$ bilhões (US $\$ 700$ milhões). Por outro lado, a criação do Fundef - um programa de incentivos à descentralização e melhoria dos salários dos professores e da performance das escolas - foi implementada ao mesmo tempo em que os gastos em educação, considerando-se todos os níveis de governo no Brasil, também se elevaram de $4,2 \%$ para 5,6\% do Produto Interno Bruto - PIB, no período 1995-2000. O número de matrículas no nível primário expandiu de $89 \%$ para 96\%, entre 1996 a 2001 (Word Bank, 2002). O processo de descentralização também se acelerou. Os governos municipais que eram responsáveis por 34\% das matrículas do ensino primário em 1996 aumentaram sua participação para 54\% das matrículas em 2001 (idem, 2002).

$\mathrm{Na}$ verdade, as mudanças ocorridas são paradoxais. Como podemos explicar as transformações que se dão no padrão das políticas sociais, se considerarmos os formidáveis obstáculos fiscais e institucionais à mudança no país, pelo menos na forma em que este é analisado na visão dominante na literatura? Tais obstáculos não se resumiriam às restrições fiscais severas, mas incluiriam também o fato de o Brasil possuir um sistema político fragmentado, conforme sugerido por vários analistas, no qual as reformas são difíceis de serem aprovadas e implementadas. Tais transformações são ainda mais intrigantes, considerando-se que, por uma série de razões que serão discutidas neste artigo, as reformas nessa área, em qualquer país, são vistas como problemáticas. As da chamada área ou setor social constituem em um subconjunto das reformas denominadas de segunda geração que apresentam características peculiares que as tornam difíceis de aprovar e, em especial, de implementar. Este artigo fornece uma explicação para esse paradoxo. A minha hipótese é que tais mudanças podem ser fundamentalmente explicadas pela reestruturação do padrão de relações intergovernamentais no país. O Executivo tinha incentivos e capacidades institucionais 
para levar a cabo tal reestruturação. No artigo, argumento que a mudança importante do federalismo brasileiro ${ }^{3}$ e a recentralização ocorrida cumpriram papel fundamental em reduzir os efeitos desorganizadores dos desequilíbrios fiscais subnacionais e do padrão centrado na patronagem prevalecente no âmbito da política social. Um resultado desse jogo foi a crescente vinculação ampla de recursos para a política social (para o que também contribuiu a interação estratégica entre o Executivo e o Legislativo em torno da extração de recursos tributários, em contexto de baixa confiança recíproca). Esse jogo representa o mecanismo central do processo de crescente enrijecimento e perda de graus de liberdade do processo orçamentário federal. Devido ao alto nível de constitucionalização das políticas públicas no Brasil, as reformas das relações federativas e das políticas sociais exigiram mudanças constitucionais importantes. Isso explica por que as reformas constitucionais se tornaram elementos vertebradores das transformações ocorridas. Este aspecto é pouco reconhecido na literatura: o federalismo representou o núcleo duro do movimento esforço de reforma da constituição desde sua promulgação.

O artigo é organizado da seguinte forma: na primeira seção, discuto os três tipos de obstáculos identificados na literatura - os associados à segunda geração de reformas, os institucionais e os fiscais - para as transformações nas políticas públicas de cortes sociais. A seção dois ocupa-se dos legados de políticas enfrentados no governo de Fernando Henrique Cardoso e discute o contexto político no qual ele implementou as reformas, com foco no jogo constitucional em torno da reforma do federalismo fiscal e das políticas sociais do país. A terceira, por sua vez, examina as iniciativas de reforma em três áreas: canalização de recursos à saúde e combate à pobreza, e o Fundef. A última sumariza as conclusões.

\section{POR QUE A REFORMA NÃO DEVERIA TER ACONTECIDO?}

\section{Contrariando as Expectativas: A Política das Reformas da Segunda Geração}

A literatura contemporânea sobre as reformas de segunda geração enfatiza que essas reformas são mais difíceis de aprovar e implementar do que suas predecessoras da primeira onda e que, portanto, os esforços de reforma têm grande chance de malograr. As reformas da primeira geração foram realizadas nos anos 1980 e início dos anos 1990, com o 
objetivo de estabilizar e liberalizar a economia. Elas consistiam de medidas pontuais como o corte no orçamento, aumento de taxa de juros, redução da oferta monetária, episódios de privatização etc. Em contraste, as reformas da segunda geração têm, em sua maioria, um foco institucional, cujos objetivos são complexos e pouco tangíveis para aperfeiçoar a provisão de serviços, as estruturas regulatórias e as capacidades administrativas (Naín, 1995). Nesta perspectiva, as transformações profundas no padrão de políticas públicas referido anteriormente exigem, sem dúvida, uma explicação.

Deve-se mencionar que muitas das diferenças identificadas na literatura entre as duas gerações não são informadas analiticamente, e sim ditadas pelas escolhas a serem feitas em termos de políticas. As reformas da segunda geração são, na verdade, um repertório de prescrições de políticas, formuladas em resposta às falhas da primeira geração de reformas (Rodrik, 2004). O mais problemático é que, como Navia e Velasco (2003) assinalam, as reformas da segunda geração se definem em termos dos resultados a serem atingidos - eficiência administrativa, eliminação da pobreza, ambientes regulatórios adequados e estáveis mas tais resultados (ao contrário, por exemplo, de metas de inflação a serem atingidas, típicas das primeiras reformas) são os que tornam "avançadas as nações avançadas". A despeito desses problemas de definição de reformas de segunda geração, importa destacar que a literatura enfatiza uma série de fatores que contribuem para a dificuldade de realização das reformas institucionais e sociais (Graham e Naín, 1999; Pastor e Wise, 1999; Nelson, 2000; 2004; Grindle, 2000; Kauffman e Nelson, 2004a; Schneider e Heredia, 2003; Tulchin e Garland, 2000; Nelson e Tommasi, 2002). Primeiro, os "custos de não reformar" são baixos (Nelson, 2000), o que tende a produzir inércia decisória. No caso da primeira geração, os "custos de não reformar" foram altos, visíveis e difusos (na forma de inflação, por exemplo). Muitos analistas tentaram modelar as causas de tais reformas, identificando os fatores mais prováveis de provocar impactos de curto prazo na inflação, receita governamental, deflagrando processos de reforma. Nas reformas de segunda geração não existem tais fatores, nem mesmo um senso de urgência, o que significa que elas podem ser postergadas indefinidamente. Como assinalam Kauffman e Nelson (2004b), nessa área as urgências são prementes, e os incentivos para a reforma, fracos. Com freqüência, a reforma da educação ou as reformas regulatórias, em geral, são citadas como bons exemplos disso. 
Em segundo lugar, a primeira onda de mudanças foi levada a efeito em situações de emergência, tendo sido implementada pelo Executivo mediante uma série de instrumentos políticos (decretos especiais de emergência ou leis delegadas), sem muita necessidade de negociação no Congresso ou com os interesses afetados. Em contraste, as novas reformas têm sido implementadas em ambientes mais democráticos, requerendo a formação de consenso, têm que ser negociadas no Congresso para a obtenção de apoio Legislativo. A política congressual "ordinária" substitui a política "extraordinária", típica de medidas de emergência (Nelson, 2000). Além disso, as reformas de segunda geração envolvem a cooperação dos atores, em diferentes níveis do aparato estatal, criando a possibilidade de pontos de veto. Muitas das reformas da primeira onda na América Latina foram realizadas furtivamente. Só exigiram decisões executivas nas áreas do comércio exterior, monetária e fiscal, que são, em grande medida, simples e self-enforced. A implementação foi razoavelmente fácil por não requerer cooperação externa. A reforma do sistema educacional, por exemplo, normalmente envolve tarefas bastante complexas, tais como as que buscam alterar as rotinas burocráticas estabelecidas ou aperfeiçoar a qualidade dos serviços prestados e a descentralização, as quais sem cooperação dos professores têm baixas chances de sucesso. Em terceiro lugar, elas envolvem o realinhamento de incentivos, gerando custos concentrados importantes para certos setores, como sindicatos, burocracias ou parlamentares, ou ainda para as clientelas privilegiadas dos programas existentes (Grindle, 2001). Ao contrário das reformas da primeira geração, a cooperação desses atores - particularmente dos sindicatos do setor público - é crucial (Maceira e Murillo, 1999). Nessa perspectiva, prediz-se que, quanto mais estável ou democrático o país, em termos institucionais, se torna mais difícil aprovar e implementar reformas. Um aspecto correlato é que essas reformas se distinguem das voltadas para a expansão de cobertura, nas quais o jogo é de soma positiva; pelo contrário, é um jogo em que todos os participantes ganham. Ao contrário do processo da "política de expansão", as reformas de segunda geração concentram-se na eficiência e qualidade, o que tipicamente produz custos concentrados (e conseqüentemente um padrão político específico à "política de eficiência").

Finalmente, como destacado por Nelson (2000), ao contrário das políticas monetárias e fiscais, não há padrões ou modelos claros de políticas a serem seguidos, apenas princípios norteadores, como a descentralização, arranjos competitivos dentro do setor público e assim por dian- 
te. Isso torna difícil a formação de consenso. Navia e Velasco argumentam com muita propriedade que

"[...] ao contrário das reformas da primeira geração, que foram, de fato, diretrizes a respeito dos instrumentos a serem usados e dos resultados necessários, para a redução da inflação com o corte da oferta de moeda e do déficit em conta corrente, muitas das reformas da segunda geração são diretrizes a respeito dos resultados desejados (reforma do serviço público ou aperfeiçoamento da arrecadação tributária), sem uma idéia clara do desenho das políticas" (2003:278).

Grindle (2004) examina as reformas da educação bem-sucedidas na América Latina e discute os fatores que explicam o seu êxito, a despeito das expectativas. A autora enfatiza o papel da liderança e janelas de oportunidade. Grindle (idem) argumenta que muitos dos obstáculos citados na literatura são relacionados ao contexto e podem ser superados a partir de negociações em torno das reformas. Pela ação estratégica na definição da distribuição de custos e benefícios de determinada iniciativa de política, setores reformistas podem superam resistências.

Devido à sua ênfase no desenho das políticas, no entanto, a autora não destaca o papel independente das instituições políticas, especialmente das relações Executivo-Legislativo, na sua explicação. Ainda que explorem janelas de oportunidade, os reformadores operam dentro de um conjunto institucionalmente constrangido por regras que definem as capacidades e os incentivos que têm para realizar a reforma.

A "abordagem das gerações de reforma" tem sido tema comum na discussão da dinâmica das reformas de políticas, e é a linguagem que informa o debate sobretudo no âmbito das instituições multilaterais. Essa abordagem padece de problemas para a discussão de países, tais como o Brasil, onde os dois tipos de reformas se confundiram com o passar do tempo. As do primeiro tipo - privatização, estabilização monetária e liberalização do mercado - foram implementadas simultaneamente com reformas regulatórias, administrativas e - o que é mais importante para os nossos propósitos aqui - dos setores sociais. Embora Fernando Collor de Mello (1991-1992) tenha tomado algumas medidas para privatizar as empresas estatais, foi o governo de Fernando Henrique Cardoso que promoveu a privatização em larga escala de empresas públicas. Seu governo engajou-se simultaneamente em ambicioso programa de estabilização, deflagrando um processo de reforma do sistema previdenciário, da administração pública e dos setores sociais. 
O ímpeto reformista de sua administração arrefeceu ao longo do tempo na passagem do primeiro para o segundo mandato. A estratégia de empreender reformas simultaneamente em vários setores exigiu muita negociação no Legislativo e nutriu-se do sucesso do plano de estabilização monetária. O big bang do governo de Fernando Henrique Cardoso (Navia e Velasco, 2003) - o lançamento simultâneo dos dois tipos de iniciativa de reforma - contrasta com a trajetória e seqüências observadas em muitos países da região. O enorme sucesso na redução da inflação foi essencial para superar muitos dos obstáculos apontados pela literatura ${ }^{4}$. Isso lhes permitiu fazer mudanças em larga escala ao mesmo tempo em que fortaleceu as bases institucionais do Executivo (Alston et alii, 2004; ver também Treisman, 2004).

A hipótese central deste artigo é que a capacidade do Executivo (e seus incentivos) para implementar reformas é explicada por uma combinação de variáveis institucionais e de desenho de políticas. Na seção seguinte, discutirei as bases institucionais da reforma das políticas sociais. Nela examino a visão predominante sobre a natureza do sistema político brasileiro e analiso sumariamente a recente produção acadêmica que desafia tal visão.

\section{Instituições Políticas e a (In)capacidade de Reformar}

A visão da literatura comparativa sobre as políticas de reforma é que as instituições políticas brasileiras geram paralisia decisória e inércia política. Espera-se que as reformas só venham a ocorrer após negociações prolongadas envolvendo o presidente e o Congresso, e com um alto custo social (Samuels, 2003; Ames, 2001; Mainwaring, 1999). Os problemas de governabilidade seriam causados por diversas características do sistema político, tais como a estrutura federativa, o bicameralismo simétrico, o presidencialismo e as instituições eleitorais. O sistema político tem sido descrito como excessivamente descentralizado e fragmentado. Para Mainwaring e Shugart (1997), o federalismo brasileiro é robusto e apresenta grande desequilíbrio. Essa perspectiva de análise destaca que os estados gozam de autonomia fiscal e política, e que aproximadamente metade da receita pública está nas mãos dos estados e dos 5.600 municípios. Além disso, um terço das receitas fiscais é arrecadado diretamente pelos governos subnacionais, e os estados têm a competência de arrecadar o imposto que gera mais receita (VAT). Apesar das enormes diferenças econômicas e demográficas, os estados dispõem de igual representação no Senado. Esta representação exage- 
rada dos estados menores e menos desenvolvidos repete-se em grau muito menor na Câmara dos Deputados, na qual as unidades menores têm um número proporcionalmente maior de deputados. Tal característica se combina com um padrão de lealdades de corte regional, produzindo um sistema no qual o executivo federal tem de negociar, fazendo concessões para os interesses subnacionais (Samuels, 2003). De acordo com essa linha de interpretação, os interesses subnacionais especialmente os governadores - exercem poderes de veto em muitas questões nacionais importantes (Ames, 2001).

Para muitos analistas, o desenho constitucional brasileiro, na verdade, contém uma combinação explosiva de presidencialismo e multipartidarismo. Os deputados federais são eleitos através de um sistema de representação proporcional em lista aberta, e os estados são distritos-membros, cuja magnitude varia de oito a 70. Após a mudança para a democracia, em 1985, o sistema bipartidário que existia no regime militar deu lugar a um sistema multipartidário com um número enormee sempre crescente - de partidos efetivos (oito). A disciplina partidária também é fraca, uma vez que a lista aberta encoraja os comportamentos individualistas dos parlamentares e não permite muito controle partidário na seleção dos candidatos. Conseqüentemente, os partidos não têm conseguido criar fortes identidades nem possuir raízes profundas com a sociedade. A migração interpartidária de parlamentares (pelo menos dentro de um "espaço" ideológico aproximadamente similar) enfraquece a base organizacional dos partidos. O sistema político emergente no Brasil tem sido descrito como um presidencialismo de coalizão. Os presidentes, bem como os governadores e prefeitos, são eleitos pelo voto direto e contam com o apoio de grandes coalizões. No governo de Fernando Henrique Cardoso, nenhum dos três maiores partidos - incluindo o dele (Partido da Social Democracia Brasileira PSDB) conseguiram mais do que 20\% dos assentos da Câmara dos Deputados.

Como já amplamente reconhecido, o problema dessa linha de interpretação é que ela subestima as conseqüências de o presidente possuir grande poder, incluindo uma série de prerrogativas que o ajudam a superar a fragmentação partidária e assegurar a implementação de sua agenda (Figueiredo e Limongi, 1999). O grande número de prerrogativas inclui, inter alia: uso de medidas provisórias (MPs) - decretos com força de lei, que têm de ser votados em 30 dias (e que mudou para 60 dias), caso contrário perderiam sua eficácia; competência exclusiva 
para propor legislação tributária, fiscal e administrativa; faculdade de exigir votação imediata de determinados projetos de lei; e veto parcial. Tudo isso se adiciona ao controle da patronagem na imensa máquina administrativa federal e da elaboração discricionária de emendas orçamentárias pelos parlamentares (Pereira e Mueller, 2003; Souza, 2003). A organização interna do Congresso proporciona também instrumentos importantes para a administração da coalizão pelo Executivo. $\mathrm{O}$ Congresso é estruturado a partir de uma lógica partidária que confere grandes poderes aos líderes dos partidos (Figueiredo e Limongi, 1999). Segundo Alston et alii (2004), isso não significa que o Congresso é inerte. Na verdade, o presidente age como gestor da coalizão e negocia a distribuição de favores em troca de suporte para sua agenda.

Em suma, há um grande número de forças centrípetas e centrífugas no sistema político brasileiro. Exemplos das primeiras são a legislação eleitoral, a autonomia fiscal subnacional, o regionalismo e o faccionalismo de base regional, além de partidos fracos e sistemas partidários fragmentados. As segundas têm origem nos poderes constitucionais dos presidentes, bem como na organização interna do Congresso e, o que é mais significativo, nos imensos recursos controlados pelo presidente, os quais podem ser usados para garantir apoio político. São forças notadamente clientelistas - como programas de distribuição de favores para a base constituinte de determinado parlamentar - ou, simplesmente, conseqüências da participação no governo. A capacidade política dos presidentes é essencial para a superação das forças fragmentadoras do sistema político. As forças centrípetas acima mencionadas representam restrições importantes à capacidade do presidente em aprovar e implementar sua agenda (idem, 2004). Meu argumento é que os presidentes operam em um espaço político e institucional sujeito a restrições, o que não tem, todavia, produzido impasses ou entraves significativos. Os presidentes tiveram os incentivos e a capacidade de implementar suas agendas de reformas. A estrutura de incentivos com a qual os presidentes se defrontam será discutida na seção seguinte.

O senso comum a respeito das questões fiscais do Brasil é que um dos principais problemas se encontra no sistema de relações intergovernamentais do país. O suposto excessivo poder exercido pelos interesses subnacionais, em particular os governadores estaduais, provocaria fortes distorções de natureza fiscal (Burki, Perry e Dillinger 1999; Dillinger e Webb, 1999; Haggard e Webb, 2004). Rodden (2003:213) enfatiza a "gravidade dos desafios para a gestão macroeconômica impostos 
pela descentralização fiscal num contexto de desigualdades, fragmentação política e um federalismo robusto", mas não é capaz de fornecer uma explicação para as medidas radicais e recentralizadoras adotadas pelo governo de Fernando Henrique Cardoso nessa área. Sem dúvida, se "o 'centro' [governo federal] for pouco mais do que uma tênue coalizão de grupos de interesse baseados nos estados" (Rodden, 2003:244), como tais medidas poderão ser explicadas? De acordo com esse argumento, a descentralização no Brasil tem gerado mais problemas do que benefícios. A visão do "federalismo predatório" (Abrucio, 1998) - um executivo federal fraco, incapaz de superar as pressões da periferia do sistema político - é estranha ao quadro do federalismo no governo de Fernando Henrique Cardoso. Como afirmei no início do artigo, esse argumento não é consistente com a transformação observada no padrão das políticas públicas sociais no Brasil. Neste artigo, argumento que ocorreu uma transformação importante na estrutura federativa brasileira, que foi essencialmente uma reação ao choque externo produzido pela Constituição de 1988.

A revisão da literatura apresentada nesta seção sugere que o Brasil não é um caso provável de sucesso na reforma das políticas sociais. Mas há bases empíricas e analíticas para se esperar o contrário. Como assinalado, o padrão de relações Executivo-Legislativo pós-constituinte, na realidade, indica que o Executivo tem poderes institucionais importantes para aprovar políticas e implementar sua agenda. Minha hipótese é que um importante fator que viabilizou a implementação da agenda de reformas nos setores sociais foi a capacidade do governo de reestruturar as relações intergovernamentais - particularmente o federalismo fiscal do país. Vale ressaltar que outros aspectos também importaram, como a reorganização do lugar da política social na distribuição negociada do portfólio ministerial, e ao mesmo tempo a redefinição do padrão de patronagem nessa área. A estratégia big bang utilizada, em razão da qual o apoio ao seu programa de estabilização monetária se estendeu às suas outras iniciativas, foi também parte integrante do apoio dado ao programa de reforma das políticas sociais nos dois governos do presidente Fernando Henrique Cardoso.

\section{CONCILIANDO A REFORMA DE POLÍTICA E O MANEJO DA COALIZÃO DE GOVERNO}

Nesta seção examino três processos inter-relacionados. Em primeiro

lugar, discuto como o Executivo pôde levar a cabo uma reforma impor- 
tante das relações financeiras intergovernamentais; Em segundo lugar, demonstro como o federalismo e a política social estavam no núcleo duro do processo amplo de reforma constitucional da década de 1990; e, finalmente, apresento evidências de que houve modificações importantes no lugar ocupado pelos ministérios sociais na política de montagem de gabinetes de coalizão.

\section{Incentivos Presidenciais, Restrições Fiscais e Federalismo}

A Constituição de 1988 foi elaborada sob circunstâncias excepcionais. O Executivo não desempenhou efetivamente qualquer papel no processo, enquanto os atores subnacionais, em particular os governadores, jogaram um papel central. Dado que as primeiras eleições diretas durante o jogo de transição política foram para governador, em 1982, os governadores adquiriram grande legitimidade e tornaram-se os guardiões do novo regime, negociando ativamente a transição com os militares. O processo de elaboração da Constituição foi, portanto, marcado por uma forte influência dos interesses subnacionais. As implicações fiscais da Constituição foram percebidas no início dos anos 1990, e a subseqüente evolução das relações intergovernamentais no governo de Fernando Henrique Cardoso refletiram a reação do governo federal contra tal estado de coisas.

Como Alston et alii (2004) argumentam, os presidentes brasileiros têm fortes incentivos para estabilizar a economia e adotar políticas fiscais sólidas basicamente em função de dois fatores. O primeiro é que o eleitorado se tornou altamente avesso à inflação, principalmente depois dos efeitos devastadores da hiperinflação na vida dos brasileiros nos anos 1980 e início dos anos 1990. Por conta das experiências heterodoxas fracassadas durante os governos de José Sarney e Fernando Collor de Mello - Planos Cruzado e Collor, respectivamente - os cidadãos estavam dispostos a punir eleitoralmente os governos que implementassem práticas fiscais heterodoxas. Mas o Executivo federal teve que conciliar suas preferências fiscais com medidas que teriam conseqüências na sua sobrevivência política, inclusive nas áreas de políticas pelas quais eles arcariam os custos políticos no caso de fracasso. Apesar do controle da inflação, os presidentes seriam punidos pelo aumento da taxa de desemprego e pela baixa performance dos indicadores sociais que adquiriram crescentemente visibilidade nas áreas de saúde e educação. A capacidade do Executivo em conciliar esses dois imperativos explica parte do seu sucesso. 
As estratégias políticas do governo de Fernando Henrique Cardoso foram profundamente constrangidas pela agenda política que herdou e que ele próprio ajudou a formar. Os elementos mais importantes dessa agenda foram os seguintes: em primeiro lugar, a sustentabilidade do Plano Real. A primazia deste na agenda de governo deve-se ao fato de ter sido o sucesso do Plano que, primeiramente, conduziu Fernando Henrique à presidência (o que aconteceu também com os governadores que se beneficiaram dos efeitos de coattail [efeito de uma eleição sobre outra] produzidos em 1998). Além de ter sido escolhido como candidato à presidência por causa do Real, sua reeleição na campanha presidencial de 1998 também dependeu do seu sucesso em controlar a inflação. Isso explica por que a sustentabilidade do Plano Real se tornou, ao longo do tempo, um elemento essencial do discurso e da prática política da sua coalizão de governo. As falhas sucessivas dos planos de estabilização - principalmente o Plano Collor, que congelou os preços e impediu, durante um ano, a utilização da poupança e das aplicações financeiras mantidas pelos agentes econômicos - causaram grande impacto na população. No segundo mandato de Fernando Henrique Cardoso, a questão fiscal adquiriu importância ainda maior devido à corrida contra o Real, no final de 1998, que teve início com a crise da Rússia, provocou a desvalorização da moeda e uma grande instabilidade nos mercados internacionais.

A inflação era percebida como sendo causada, em primeiro plano, pela dívida do setor público. Várias medidas foram tomadas para estabilizar a economia no primeiro governo de Fernando Henrique Cardoso, inclusive a privatização das estatais - particularmente as empresas de utilidade pública - com a redução do número de funcionários federais e do gasto com pessoal, bem como a reforma da previdência social. Enquanto o governo federal implementava tais medidas, os estados e municípios operavam em uma situação de soft budget constraint - restrição orçamentária fraca - com elevado e crescente endividamento. A dívida subnacional tornou-se a fonte primária de desequilíbrio fiscal no país. Os estados operavam fora do controle do Banco Central, uma vez que os tesouros estaduais emitiam títulos da dívida, os quais eram absorvidos por instituições do setor público financeiro estadual. Isso culminou na inadimplência do Estado de Minas Gerais em 1998, que teve fortes impactos no risco-país no curto prazo. Defrontando-se com tal estrutura de incentivos, o executivo federal engajou-se em uma sé- 
rie de reformas que redefiniram as relações financeiras intergovernamentais.

A primeira iniciativa importante foi a renegociação da dívida dos estados, que ocorreu em meados dos anos 1990 e envolveu a federalização de aproximadamente US\$ 80 bilhões de débito subnacional. Em troca do refinanciamento da dívida, o governo federal impôs várias condicionalidades, dentre as quais a privatização dos bancos e das empresas públicas estaduais (a maioria delas fornecedoras de energia elétrica). Ao mesmo tempo, o governo federal aprovou diversas emendas constitucionais, estipulando mecanismos mais restritos de suspensão de transferências previstas na Constituição para os estados inadimplentes. A estratégia federal esteve ancorada fundamentalmente em jogo de cenoura e porrete, no qual os primeiros foram operações de adiantamento pelo Banco Nacional de Desenvolvimento Econômico e Social BNDES de recursos em antecipação às receitas futuras dos leilões de privatização.

A estratégia fiscal do governo federal na administração de Fernando Henrique Cardoso também envolveu o aumento da carga tributária (através de impostos não sujeitos à partilha federativa), ao mesmo tempo em que restringiu o comportamento fiscal das unidades subnacionais. Entre 1994 e 2002, a carga tributária subiu de $24 \%$ para $34 \%$ do PIB - um acréscimo de $10 \%$ em uma única década. Isto se deu principalmente através das contribuições sociais - tributos cujas receitas não são constitucionalmente partilhadas com os estados e municípios. A parcela das contribuições na receita total cresceu de $11 \%$ para $49 \%$. Como resultado, até o final da década de 1990, dois terços de toda a receita arrecadada pela Receita Federal vieram das contribuições (ver Gráfico 1). O aumento dos impostos federais concentrou-se nas chamadas contribuições sociais por três razões. Ao contrário do imposto de renda e do Imposto sobre o Valor Acrescentado - IVA, elas não requerem a partilha com os estados e municípios. Além disso, a exigência de que os novos impostos só podem entrar em vigor no ano fiscal seguinte não se aplicava a elas, as quais já podiam ser cobradas depois de três meses. Em terceiro lugar, o principal componente do déficit fiscal era a dívida da previdência social, de mais de $4 \%$ do PIB, que foi em parte financiada com o aumento das contribuições. Essa dívida tinha dois pilares: o desequilíbrio atuarial do sistema especial de pensão dos servidores públicos e o imenso regime não-contributivo das pensões rurais (Melo, 2004). 


\section{Gráfico 1}

Porcentagem na Receita Total Arrecadada pela SRF

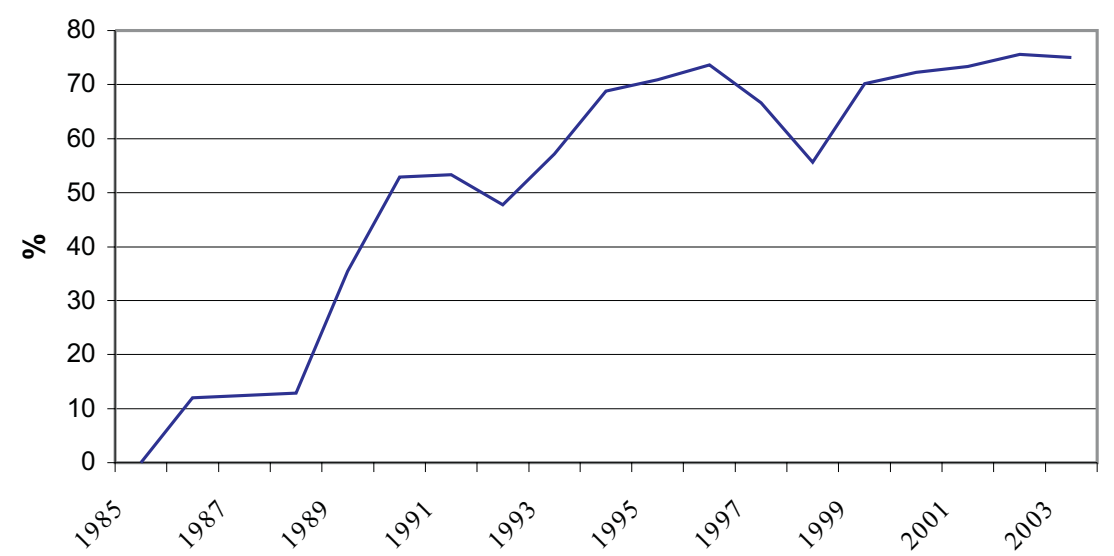

Fonte: Elaboração do autor a partir de dados primários disponíveis em www.stn.fazenda.gov.br

O governo federal conseguiu também reter parte dos fundos que eram previstos constitucionalmente para distribuição entre os estados e municípios. Para tanto, aprovou várias emendas constitucionais que desvinculavam os impostos de aplicação específica. Antes da distribuição, os recursos alimentariam um fundo controlado pelo governo federal (o Fundo Social de Emergência - FSE) por um período específico de tempo. Essa estratégia contábil foi reafirmada posteriormente com o Fundo de Estabilização Fiscal - FEF e, mais recentemente, com a Desvinculação de Receitas da União - DRU (ver Gráfico 2). O governo federal conseguiu flexibilizar a parcela de recursos discricionários no orçamento e, ao mesmo tempo, limitar a autonomia fiscal dos estados e municípios. O ápice desse processo foi a aprovação da Lei de Responsabilidade Fiscal, em maio de 2000. Como resultado, os três níveis de governo começaram a produzir superávits primários desde 2001 (Alston et alii, 2005; Alston et alii, 2004; Schneider, 2004).

Em suma, o governo federal ajustou-se razoavelmente às restrições fiscais impostas pela alta dívida interna do país (Alston et alii, 2004; Goldfajn e Guardia, 2003). O governo conseguiu controlar a principal fonte de desequilíbrio - o comportamento fiscal subnacional - e, ao mesmo tempo, elevar a carga tributária. Isto exigiu uma dupla estratégia. Por um lado, reduziu o gasto subnacional e limitou a autonomia fiscal dos estados e municípios. Por outro, alargou o espaço fiscal do Poder Executivo federal, ao expandir a base tributária ao seu dispor e, ao mesmo 
Gráfico 2

Evolução da Composição da Receita Orçamentária

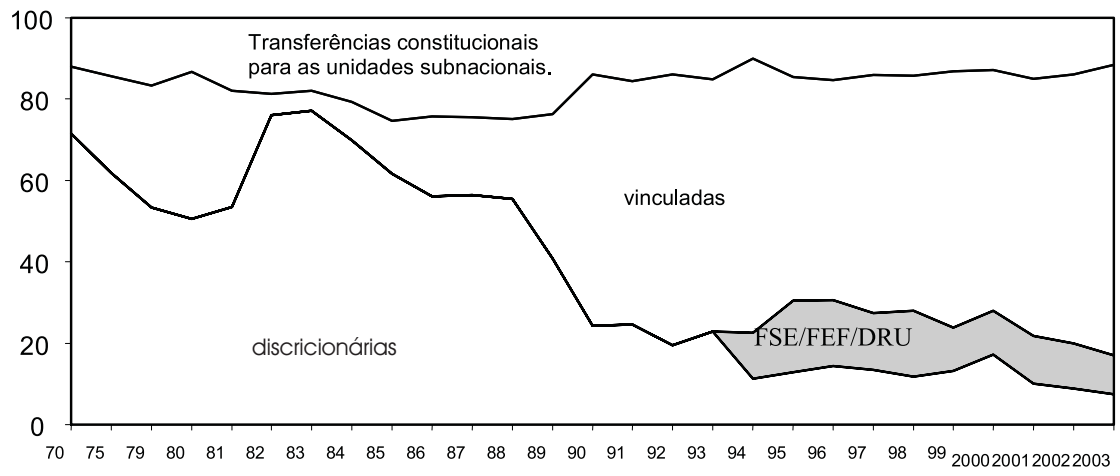

Fonte: Consultoria Legislativa do Congresso Nacional

Nota: excluindo-se privatizações e emissão de títulos da dívida.

tempo, ampliar sua discricionariedade. No restante deste artigo, discutirei como esse processo ocorreu no setor social.

\section{A Trajetória das Reformas Constitucionais}

Como afirmei anteriormente, a reforma dos setores sociais implicaram em importantes mudanças na Constituição de 1988. A Constituição representou o momento fundador de um novo padrão, com importantes conseqüências path dependent [dependente da trajetória]. O texto constitucional incorporou uma série de demandas políticas, sociais e corporativistas, não atendidas. A Constituição ficou inusitadamente longa, com 250 artigos no texto principal e outras 75 disposições constitucionais transitórias, abrangendo várias questões de políticas específicas e não-constitucionais. Esta hiperconstitucionalização da política pública reflete a sobrecarga da agenda do novo regime democrático e a insatisfação com os padrões observados na formulação de políticas nos governos militares. A Constituição incorpora as exigências em torno de uma formulação de políticas mais descentralizada, democrática e de interesse público. Em termos de relações fiscais e intergovernamentais, a Constituição devolveu autonomia administrativa aos governos subnacionais e determinou uma nova redistribuição funcional de responsabilidades. Além disso, ela instituiu um novo regime de atribuições tributárias no qual os estados e municípios receberam não apenas novos poderes de tributar, mas conseguiram, também, assegurar uma parcela maior das receitas tributárias federais. 
A Constituição concedeu um novo status constitucional aos municípios - o único país do mundo a fazer isto - que, juntamente com os estados, se tornaram unidades constituintes autônomas da federação. Criou também novas receitas para os estados e municípios, ao estabelecer novas transferências automáticas de recursos federais. A Constituição determinou também a descentralização de políticas públicas em um grande número de áreas sociais, como saúde, educação e assistência social. Além disso, instituiu arranjos participativos em diferentes níveis, tendo por objetivo o controle social. Suas inovações específicas foram: a redistribuição gradual da receita pública - os estados e municípios garantiram uma parcela maior das receitas tributárias, $10 \%$ e $15 \%$, respectivamente; a exigência de que a participação comunitária, o universalismo, a transparência e a redistribuição sejam estabelecidos como princípios para a organização da administração pública; e diversos dispositivos específicos de natureza redistributiva, que ampliaram consideravelmente os direitos sociais, tais como a equalização dos benefícios de seguridade social urbanos e rurais. Muitas das reformas subseqüentes do governo de Fernando Henrique Cardoso implicaram, portanto, em questões de desconstitucionalização, ou seja, a supressão de artigos da Constituição e posteriormente (mas nem sempre) introdução de legislação sobre a questão por meio de leis ordinárias. O nível inicial de constitucionalização produziu grande rigidez nas políticas públicas em geral (Melo, 2002; 2003; Alston et alii, 2005). Isto, todavia, não impediu que o governo de Fernando Henrique Cardoso aprovasse seus programas de reforma. Um alto grau de constitucionalização afeta a formulação de políticas sociais, porque, especialmente em uma federação grande e robusta como o Brasil, onde os municípios são consideravelmente autônomos, qualquer mudança nas relações intergovernamentais ou na taxação requer alterações na Constituição. A maior parte das iniciativas na política social e redução da pobreza foi implementada via emendas constitucionais, o que envolveu intensas negociações dentro da coalizão governamental e com a oposição.

Os Gráficos 3, 4 e 5 fornecem dados sobre as 50 emendas à Constituição de 1988, apresentadas até janeiro de 2004. Dez das emendas procederam a Era Cardoso, ao passo que cinco foram promulgadas no primeiro ano do governo de Luiz Inácio Lula da Silva (duas das quais foram propostas pelo governo de Fernando Henrique Cardoso, mas promulgadas posteriormente). Quase metade (42\%) das emendas constitucionais aprovadas refere-se diretamente a aspectos do federalismo brasileiro. Para as emendas propostas durante os dois mandatos de Fernando 
O Sucesso Inesperado das Reformas de Segunda Geração...

Gráfico 3

Emendas Constitucionais por Área Temática

1989-2004

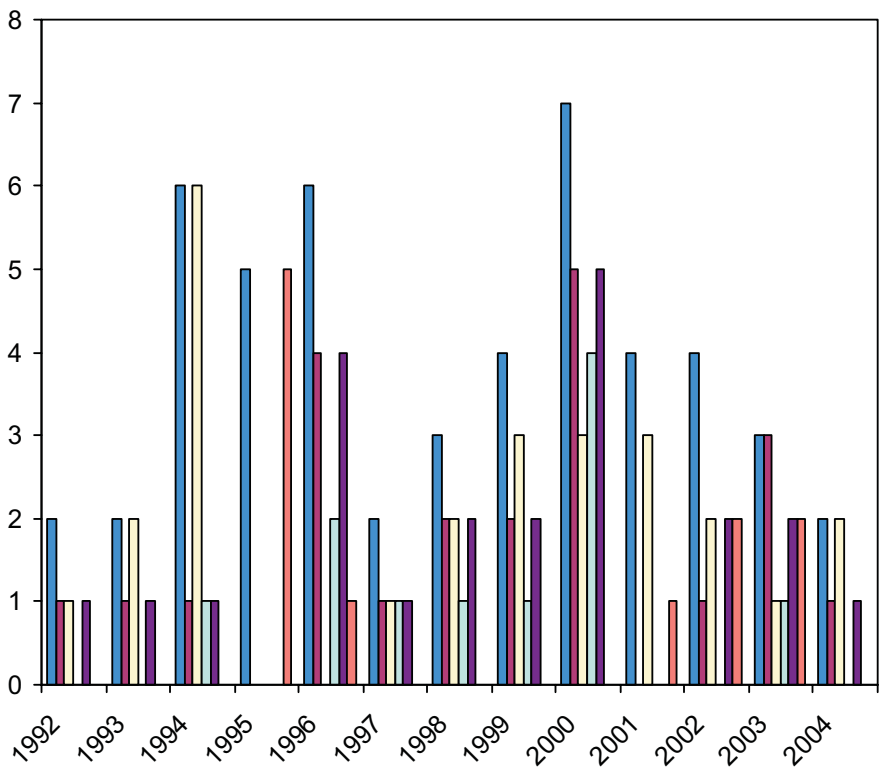

$\square \mathrm{N}^{\circ}$ Total de emendas

$\square$ controle fiscal

$\square$ questões institucionais

$\square$ política social/direitos sociais

$\square$ federalismo

$\square$ economia

Fonte: Melo (2006). Elaboração própria do autor com base em dados do Ministério da Justiça.

Gráfico 4

Quantidade de Emendas Constitucionais por Ano de Apresentação

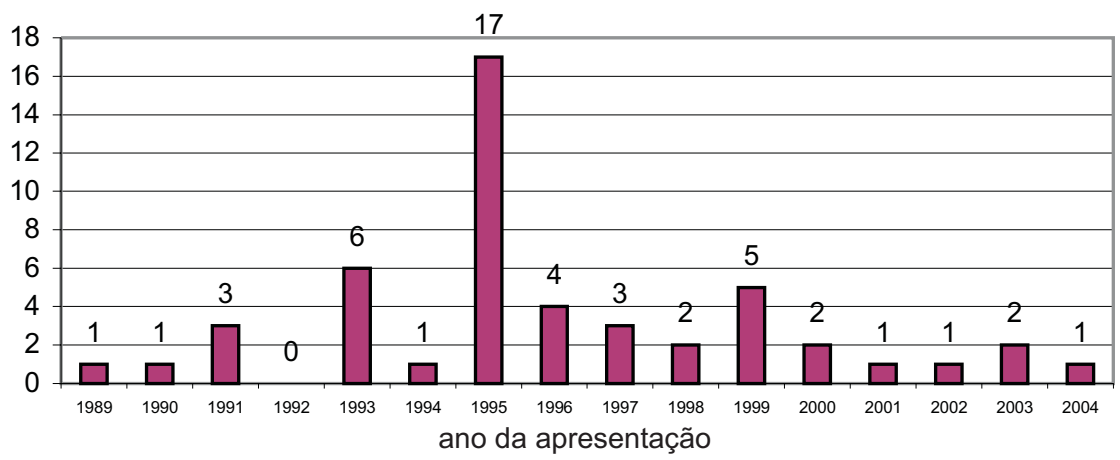

Fonte: Melo (2006). Elaboração própria do autor com base em dados do Ministério da Justiça. 
Gráfico 5

Quantidade de Emendas Constitucionais por Ano da Promulgação 1989-2004

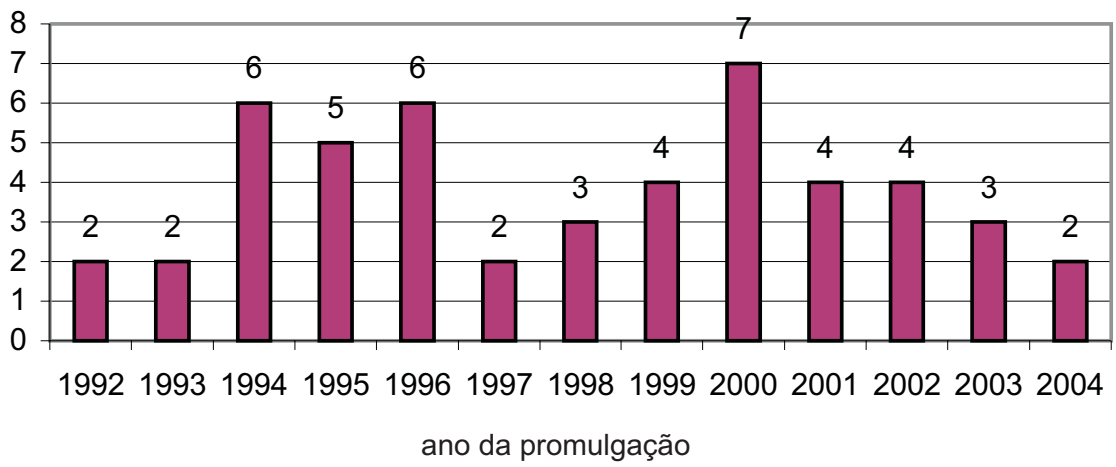

Fonte: Melo (2006). Elaboração do autor com base em dados do Ministério da Justiça.

Henrique Cardoso, o número correspondente é maior ainda $(48,5 \%)$. Do total de emendas pertinentes ao federalismo, mais da metade (53\%) relaciona-se a políticas e direitos sociais ${ }^{5}$. A centralidade dessas questões no processo de mudança constitucional pode ser medida em comparação com outros grandes temas. Enquanto o federalismo foi questão temática em quase metade das emendas, a economia e os aspectos "institucionais" não-relacionados ao federalismo foram o alvo de, respectivamente, $22 \%$ e $32 \%$ de todas as emendas. Deve-se notar também que houve um intenso esforço reformista no primeiro ano do governo de Fernando Henrique Cardoso - 1995 (veja os Gráficos 4 e 5). Esse foi o ano do big bang de Fernando Henrique Cardoso, com uma grande concentração de emendas: metade de todas as emendas propostas pelo seu governo - e mais de um terço ( $34 \%$ ) das que foram apresentadas em um período de 16 anos.

Como se vê, a política social e o federalismo adquiriram grande centralidade no esforço reformista do governo de Fernando Henrique Cardoso. Na realidade, grande parte das transformações ocorridas no padrão da política social no período foi viabilizada através de mudança constitucional e se inscrevem em um processo de reação à hiperconstitucionalização ocorrida. O êxito desse movimento reformista é a fortiori mais surpreendente tendo em vista as dificuldades procedimentais para a aprovação de emendas à Constituição (aprovação em dois turnos nas duas Casas legislativas, maioria de três quintos, dentre outras) em relação à aprovação de legislação ordinária. 


\section{O Portfolio Ministerial e o Novo Lugar da Política Social}

Uma mudança importante ocorreu no papel dos ministérios e burocracias centrais da área social na formação de gabinetes no país. No período democrático recente, a estabilidade das coalizões políticas é determinada em grande medida pela taxa de coalescência entre o portfolio ministerial e a base aliada (Amorim Neto, 2002). Esse padrão é determinado, como amplamente discutido, pela natureza do presidencialismo brasileiro que se assenta em grandes coalizões. Ao contrário de países de desenho constitucional majoritário, o espaço político para as iniciativas do Executivo é fortemente constrangido, e a política de coalizão é um traço essencial do sistema político brasileiro (idem, 2002; Loureiro e Abrucio, 1999). Esta formulação geral não deve obscurecer uma mudança importante no conteúdo setorial das negociações. Nos gabinetes pré-Fernando Henrique, os ministérios sociais participaram da partilha de recursos organizacionais como moeda de troca com partidos da base. Os ministérios da área econômica, as empresas estatais e bancos públicos federais eram reservados à cota pessoal do presidente ou no mínimo ao seu partido. A distribuição de pastas na área de infra-estrutura tradicionalmente ocupava o segundo no ordenamento de preferências do Executivo. Nos dois governos de Fernando Henrique, os ministérios da área social foram preservados para os setores mais próximos do Executivo. Os ministérios da área de infra-estrutura, por sua vez, foram distribuídos para os parceiros da coalizão de apoio. Um indicador relevante das preferências do Executivo é a taxa de turnover no cargo. Conforme mostram os Gráficos 6 e 7, o tempo médio de permanência no cargo dos ministros da área social é muito mais elevado durante o governo de Fernando Henrique Cardoso do que nos governos anteriores. No âmbito do governo de Fernando Henrique Cardoso, a taxa de turnover na área social é semelhante à observada na área da Fazenda - apenas um ministro ocupou o cargo nos ministérios da Fazenda e da Educação durante os oito anos de mandato. O perfil dos ocupantes também muda no plano social de ministros que estão entre as lideranças importantes (do Partido da Frente Liberal - PFL no caso da educação), para ministros de perfil eminentemente técnico, ou com forte componente técnico (todos os ministros das áreas de Educação e Saúde apresentam forte formação técnica). O perfil da área social contrasta com a da infra-estrutura, na qual o número de ministros é, não só elevado (os ministérios dos Transportes e Indústria e Comércio tiveram seis e oito ocupantes, respectivamente), mas também de perfil po- 


\section{Marcus André Melo}

\section{Gráfico 6}

Volatilidade dos Ocupantes dos Ministérios da Educação

Meses no Cargo Ministro Educação - Sarney a FHC

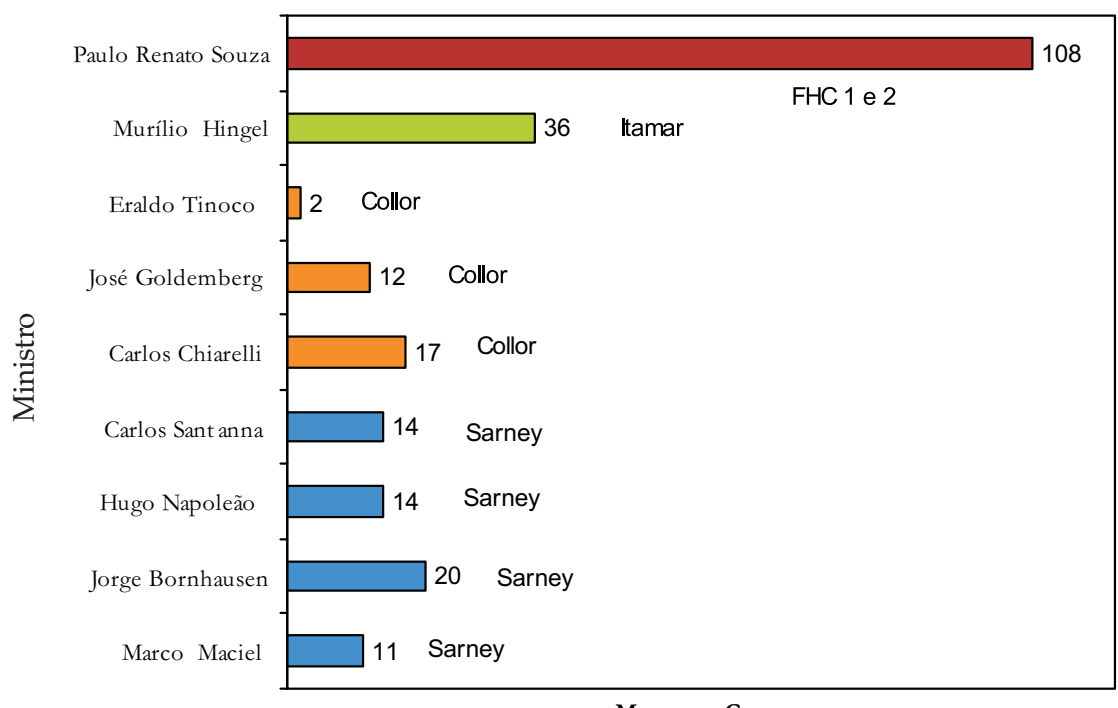

Meses no Cargo

\section{Gráfico 7}

Volatilidade dos Ocupantes dos Ministérios da Saúde

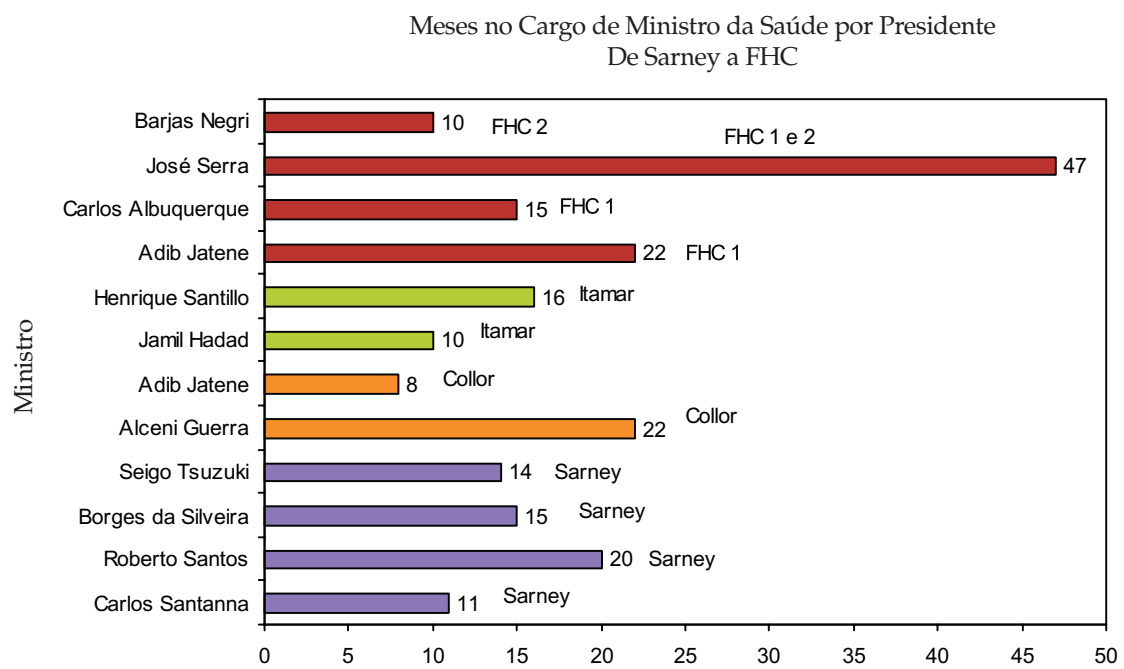


lítico - todos os ex-ministros de Minas e Energia e de Transportes foram parlamentares, este último com uma singela e breve exceção.

Vale ressaltar, no entanto, que a estratégia de insulamento da área social se restringia às estruturas centrais dos ministérios. As representações regionais desses ministérios, bem como as fundações, autarquias e órgãos nos estados eram peças importantes nos esquemas clientelistas dos parceiros da coalizão do governo, que praticamente manteve inalterado o padrão de patronagem na periferia de sua estrutura organizacional. Daí ter me referido no início deste artigo ao processo de "periferização" da patronagem na área social. O governo optou por insular a administração central, para a qual indicou especialistas, muitos deles com formação em economia. Pela primeira vez, foram nomeados economistas para os cargos de ministro da Economia e da Educação e também para secretário executivo (o segundo em importância, depois do ministro) nas duas organizações ${ }^{6}$. Em suma, ao longo dos dois mandatos, observou-se uma mudança no papel desses ministérios que importou em uma estrutura dupla na gestão social: a estrutura organizacional central foi insulada do mercado político, ao mesmo temo em que se reproduzia na periferia do sistema o mecanismo tradicional de alianças e patronagem. Embora o governo tenha deixado tais estruturas fora do alcance dos seus parceiros de coalizão e reservado os principais cargos nesses ministérios para aliados leais ao partido e para especialistas, a estrutura burocrática mais ampla foi partilhada entre os parceiros da coalizão. O fortalecimento do núcleo de comando do Executivo federal permitiu assegurar a condução da política social, contrabalançando as forças centrífugas que operavam no sentido de fragmentar as políticas públicas de corte social. Esse processo representou, no plano programático e administrativo, o equivalente funcional das transformações ocorridas na gestão fiscal e das relações financeiras intergovernamentais.

\section{A POLÍTICA DAS VINCULAÇÕES NAS ÁREAS DE SAÚDE, REDUÇÃO DA POBREZA E EDUCAÇÃO}

\section{O Fundo de Combate à Pobreza}

Após uma intensa mobilização em torno do combate à pobreza no início e em meados dos anos 1990 - o que levou à apresentação de 98 propostas legislativas na Câmara e no Senado -, o Congresso criou uma Comissão Especial para examinar a questão de redução da pobreza. A 
Comissão tornou-se uma plataforma importante para os políticos de oposição criticarem as políticas do governo, particularmente a macroeconômica. A questão da pobreza tornou-se altamente politizada, gerando diversas propostas legislativas para a obtenção de recursos antipobreza. Setores conservadores e de oposição lutaram ferozmente pela autoria das propostas (Congresso Nacional, 1999). O governo de Fernando Henrique Cardoso opôs-se à idéia de um fundo porque implicaria em "rigidez orçamentária". Para os gestores macroeconômicos, a vinculação era o resultado menos preferido, ao contrário da discrição alocativa nas escolhas orçamentárias. A Comissão elaborou a emenda constitucional que criou o Fundo de Combate à Pobreza. A proposta original previa diversas fontes de receita para o fundo, inclusive a taxação da riqueza e ativos individuais, que havia sido proposta pelo presidente enquanto parlamentar. A proposta - que veio a ser a Emenda Constitucional $\mathrm{n}$ - 31 - foi aprovada através de prolongado período de negociação.

O relatório da Comissão destacou que não se propôs a criação de impostos adicionais porque a questão estava sendo discutida na proposta de reforma tributária. A alternativa foi aumentar a alíquota de um imposto já em vigor. A maior fonte de receita viria do imposto existente sobre as transações financeiras (Contribuição Provisória sobre Movimentação Financeira - CPMF). Esse imposto havia sido criado em 1993 por uma cláusula transitória da Constituição, legalmente válida por dois anos. A solução foi um compromisso no qual o governo endossaria a proposta - considerando-se a preponderância do Executivo no funcionamento do Congresso como uma precondição para que ela fosse submetida à votação - se a CPMF fosse renovada. A aprovação implicou, portanto, na troca da renovação da validade do "imposto" - a rigor, uma contribuição - pela criação de uma nova fonte de recursos. O governo apoiou a proposta da Comissão, concordando que fosse destinado ao fundo um aumento na alíquota do imposto. A Emenda Constitucional no 12/1996 havia criado a CPMF com uma alíquota de $0,25 \%$. O imposto era vinculado à área de saúde e tinha validade de dois anos. A Emenda Constitucional no 21 estendeu a validade por mais três anos. A alíquota foi elevada para $0,38 \%$ no primeiro ano, ficando em $0,30 \%$ nos dois anos restantes - mas a receita seria destinada à previdência social. O Fundo de Erradicação da Pobreza garantiu que a alíquota de $0,38 \%$ seria mantida. O fundo gerou certa rigidez porque, caso a receita anual arrecadada não alcançasse $\mathrm{R} \$ 4$ bilhões, o governo federal cobriria a diferença com a receita tributária geral. 
O presidente do Senado, Antônio Carlos Magalhães, apresentou a proposta final, que foi aprovada como a Emenda Constitucional no 31 . O partido do senador, o PFL, ficou com a maior parte dos dividendos políticos do trabalho da comissão. A emenda final foi resultado do trabalho conjunto da comissão. Note-se que, na proposta original de Magalhães, o fundo consistia de diversas fontes de receita, incluindo novos impostos (ou novas alíquotas para impostos antigos), mas não incluía nada que se relacionasse à CPMF. O governo de Fernando Henrique Cardoso aprovou a emenda constitucional e estendeu a validade do imposto para mais dois anos. Já que o fundo duraria 10 anos, a possibilidade de novas renovações estaria assim "pré-estabelecida". A tentativa prima facie de introduzir rigidez no orçamento com o propósito de redução da pobreza pode ser entendida como parte de negociações e logrolling entre os Poderes Executivo e Legislativo. O Executivo garantiu a estabilidade fiscal, ao aumentar os impostos no âmbito federal, e, em troca, o Congresso teve acesso a alguns programas de redução de pobreza protegidos contra cortes discricionários do Poder Executivojá que a emenda proibia a desvinculação de recursos do fundo. A prática de vinculação dividiu o Executivo internamente. De um lado, os gestores macroeconômicos e, do outro, os ministérios das áreas sociais. Conforme o arquiteto do FUNDEF e da proposta de sua vinculação ao setor de saúde, afirmou: "nós éramos radicalmente favoráveis e eles eram radicalmente contra" (Barjas Negri, entrevista não publicada concedida à Mônica Teixeira, 2003). O Executivo prefere discricionariedade no âmbito federal, e vinculação e controle no subnacional. Entretanto, apóia a vinculação caso o Congresso tenha sucesso no aumento da tributação e/ou no caso de haver um consenso muito forte intra-executivo. A vinculação era, portanto, um second best para o Executivo.

Para entender completamente a estratégia do Executivo, é preciso enfatizar que ele usou a pressão do PFL estrategicamente em favor do fundo. Os políticos queriam ter seus nomes associados à proposta por causa dos óbvios dividendos eleitorais que seriam gerados. Como o administrador da coalizão, o Executivo operava estrategicamente considerando as preferências dos parlamentares de sua base. O Executivo enfrentou a resistência dos seus setores fazendários e do planejamento, bem como as restrições fiscais impostas pelo acordo com o Fundo Monetário Internacional - FMI. A solução permitiu que a coalizão ficasse com a autoria da proposta, ao passo que o Executivo foi capaz de transferir para os seus parceiros o ônus pelo impacto fiscal dessa inicia- 
tiva. Fernando Henrique Cardoso também queria ter um programa que fosse carro-chefe do seu segundo mandato e esperava que inovações nas políticas sociais desempenhassem tal papel. Essa linha de interpretação é endossada por atores importantes que estiveram envolvidos no jogo político (Vilmar Faria, entrevista ao autor, várias datas; 2002). Vale reter dessa discussão que o crescente enrijecimento do orçamento federal - que ocorre sobretudo na área social e com as contribuições - é resultado desse jogo de interação estratégica entre o Executivo que busca extrair recursos crescentes da sociedade através da taxação e um Congresso que quer garantir recursos carimbados para a área social. Esse jogo não é de soma zero, porque o Executivo também tem preferência pela melhoria dos indicadores sociais. No entanto, esse jogo produziu um certo desequilíbrio dinâmico, na medida em que a elevação do gasto social em programas universalistas teve impacto difuso e não garantiu uma apropriação individualizada de benefícios, como no caso de emendas para a execução de obras de infraestrutura. Para os parlamentares, o encolhimento crescente do orçamento de infra-estrutura e a expansão crescente do gasto social representam uma perda. Mas muitos parlamentares podem se apropriar da expansão do gasto social de forma indireta seja na forma de controle da operação do programa na ponta ou através dos ganhos indiretos advindos do sucesso da coalizão de governo.

\section{A Política das Vinculações de Recursos para a Saúde}

Um passo importante para assegurar mais recursos para o social foi dado na área da saúde. Isso envolveu duas emendas constitucionais que, como já assinalado, eram necessárias face ao alto nível de constitucionalização das políticas no Brasil. Elas podem ser vistas como estratégias de introduzir inovações institucionais como mecanismos de pré-compromisso que asseguram o seu cumprimento. A vinculação representava um mecanismo para garantir credibilidade a transações políticas. Em outras palavras, compromisso intertemporal. Na ordenação de preferências do Executivo, o que importava em primeiro lugar era garantir recursos fiscais. Como já mencionado, a Constituição de 1988 criou um orçamento unificado para aposentadorias, benefícios de assistência social e saúde pública - o chamado orçamento da seguridade social. Isso era parte da demanda por um sistema universalista de proteção social e constituiu uma importante bandeira setorial na Assembléia Constituinte. Assim, foi criada uma fonte diversificada de recursos. Os grupos que apoiavam a idéia consideravam tal arranjo 
institucional um mecanismo que desvincularia as contribuições do acesso ao sistema, tornando-o mais democrático e redistributivo. Foi também com esse propósito que a Constituição garantiu acesso universal à saúde pública, através do então recentemente criado Sistema Unificado e Descentralizado de Saúde -SUDS. Introduziu também generosos benefícios de assistência social, como os três meses de licença-maternidade. Os principais componentes do orçamento da previdência social eram a Contribuição Social sobre o Lucro Líquido CSLL, a contribuição sobre o lucro líquido das empresas, a Contribuição para o Financiamento da Seguridade Social - COFINS e a Contribuição para o Financiamento da Seguridade Social. A fusão dos gastos com saúde pública e aposentadorias no mesmo orçamento produziu, ao longo do tempo, uma dinâmica de crowding out [efeito de deslocamento] do orçamento da saúde pública. Isso porque as aposentadorias são desembolsos contratuais, e não são "comprimíveis"; são fluxos de compromissos futuros que só terminam com a morte dos pensionistas. Em contrapartida, os gastos com saúde são, na sua maioria, despesas correntes, sendo, por definição, vulneráveis no contexto da gestão fiscal. Como já mencionado, os compromissos previdenciários, ao longo do tempo, comprometeram os gastos com saúde. Não levou muito tempo para a situação ficar crítica. Isso porque, antes da Constituição de 1988, os desequilíbrios fiscais na estrutura de aposentadorias não eram significativos e, mais importante ainda, as aposentadorias não eram indexadas, resultando gradualmente em uma erosão acentuada do valor real dos benefícios. Ao determinar a manutenção das aposentadorias no seu valor real, a Constituição de 1988 proibiu a utilização do valor das aposentadorias como a variável de ajuste do sistema. Além disso, ela expandiu dramaticamente o quantitativo de servidores civis no Regime Jurídico Único, pelo qual os benefícios são calculados com base na média dos últimos vencimentos, equiparou as aposentadorias não-contributivas e os benefícios sociais rurais às aposentadorias urbanas e, finalmente, fixou o piso das aposentadorias em um salário mínimo. Isso produziu um choque externo no sistema e pressionou os gastos com saúde logo após sua implementação ${ }^{7}$.

A crise na área de saúde aumentou a visibilidade das questões de saúde pública no país. O Brasil apresenta taxas de mortalidade infantil bem acima dos países com semelhantes níveis de desenvolvimento, medidas em termos de renda per capita. Como assinalado, a questão da melhoria dos indicadores sociais do governo era central na agenda do governo. Reestruturar o sistema de saúde de acordo com um estado de 
Bem-Estar universalista compatível com as condições de um país em desenvolvimento era também uma prioridade importante para o governo. Na administração de Fernando Henrique Cardoso, durante as discussões sobre como eliminar a pobreza e melhorar as condições de vida, o ministro da Saúde, Adib Jatene, começa uma cruzada para expandir os recursos da saúde pública. Muitas propostas foram apresentadas para vincular recursos para a área da saúde, as quais foram criticadas por círculos das Finanças e do Planejamento como um retrocesso que causaria mais rigidez fiscal em um contexto de declínio acelerado dos graus de liberdade do orçamento.

$\mathrm{O}$ argumento de que seriam assegurados mais recursos para a área de saúde foi usado até mesmo nas negociações que deram origem ao Fundo Social de Emergência, em 1994, que consistiria essencialmente na retenção de $20 \%$ dos impostos e contribuições, os quais poderiam, então, ser livremente alocados pelo Executivo. A estratégia de Fernando Henrique Cardoso consistiu essencialmente em dar apoio a tais propostas - as quais geraram dividendos políticos para a sua coalizão considerando que elas não entravam em conflito com seu objetivo principal da estabilidade fiscal na medida em que implicavam na expansão dos recursos fiscais disponíveis. As medidas para assegurar o financiamento da área de saúde culminaram na proposta de reformulação da CPMF e vinculação de parte dela para o sistema de saúde. Como assinalado, a CPMF foi criada pela Emenda Constitucional oㅜ 3, de 1993, um dispositivo transitório que só valeria por dois anos. Como discutido anteriormente, a primeira mudança importante aprovada pelo governo de Fernando Henrique Cardoso ocorreu em 1996, quando a Emenda Constitucional no 12 reafirmou a CPMF e a vinculou à área da saúde. Entretanto, garantir uma fonte estável de recursos para a área de saúde não foi o suficiente, considerando-se as vicissitudes do federalismo brasileiro. A implementação das políticas dependia dos governos subnacionais e dos escalões burocráticos situados na periferia da estrutura organizacional dos ministérios sociais - tais como os escritórios regionais, os departamentos e as divisões, os quais eram controlados basicamente pelos parceiros conservadores da coalizão. $O$ elemento-chave foi, contudo, o comportamento dos prefeitos e governadores. Reconhecendo que o poder deles era um impedimento ao uso efetivo dos recursos da saúde, o governo de Fernando Henrique Cardoso deu início a mudanças institucionais importantes. Nesse caso, o ministro da Saúde e futuro candidato presidencial de Fernando Henrique Cardoso, José Serra, teve um papel fundamental. Serra apoiou a 
proposta apresentada em 1995, a qual, porém, só veio a ser aprovada em 2000, na forma da Emenda Constitucional no 29. A emenda estipulou valores mínimos para os investimentos na área de saúde nos três níveis de governo. Para o governo federal, o orçamento de 2000 foi fixado com um acréscimo de 5\% em relação ao de 1999. Definiu-se que, para o período 2001-2004, o valor dos gastos em saúde seria reajustado pela variação anual do PIB nominal. 15\% desses gastos deveriam ser destinados aos procedimentos básicos de saúde pública dos municípios e distribuídos de acordo com a população. No caso dos estados, $12 \%$ da receita - deduzidas as transferências para os municípios - devem ser gastos na área de saúde. Requer-se dos municípios, por sua vez, que gastem $15 \%$ de seu orçamento na saúde pública. Os estados e municípios que tivessem em 2000 gastos inferiores ao estipulado deveriam reduzir a diferença a uma razão de um quinto ao ano. A falta de cumprimento permitiria a intervenção federal nos governos subnacionais. A lei estabeleceu também que todas as transferências seriam canalizadas para um fundo sujeito a auditorias.

As iniciativas que tinham por objetivo vincular recursos para a saúde podem ser vistas como tentativas de controlar e assegurar o gasto subnacional naquela área, em um contexto de rápida descentralização e, conseqüentemente, de grande incerteza a respeito dos resultados dessa questão cada vez mais central no governo de Fernando Henrique Cardoso. É significativo o fato de que, no contexto do ajuste fiscal, as transferências voluntárias para a saúde - que são, de longe, as maiores do país na categoria - tornaram-se cruciais para a sobrevivência fiscal dos estados e municípios. Isso tornou ainda mais crítico para o governo de Fernando Henrique Cardoso o controle do gasto subnacional, o que é consistente com o jogo político discutido na seção dois deste artigo. O Executivo prefere vincular o gasto subnacional porque isso lhe concede discricionariedade fiscal no âmbito federal e lhe possibilita superar os problemas de assimetria de informação em relação a agentes na ponta do sistema: prefeitos, governadores e burocracias responsáveis pela implementação.

\section{Mudando a Estrutura de Incentivos na Federação Brasileira: $O$ Fundef}

Em dezembro de 1996, o Congresso aprovou a Emenda Constitucional no 14, instituindo o Fundo de Manutenção e Desenvolvimento do Ensino Fundamental e Valorização do Magistério, o FUNDEF. Tendo sido 
proposto pelo Executivo federal, o Fundef representou um mecanismo engenhoso criado no governo de Fernando Henrique Cardoso para redefinir a estrutura de incentivos vigente na provisão de educação básica no Brasil. O Fundo representa um exemplo paradigmático de reforma de segunda geração. A política de educação é outra área que ilustra o uso de inovações institucionais como mecanismos de pré-compromissos para assegurar que sejam cumpridos. Como no caso da saúde pública, os ensinos fundamental e médio eram considerados cruciais pela coalizão governamental, requerendo insulamento do logrolling ordinário no Congresso. Como assinalado, o first best para o Executivo seria ter total discricionariedade na alocação de fundos na área social. Mas em troca da aprovação do Congresso para a criação de novos tributos, ou para a instituição de programas que aumentariam o controle do governo central no gasto subnacional, a vinculação representava $o$ second best. Sem dúvida, no caso do Fundef, o controle fiscal e a elevação do desempenho educacional eram os objetivos principais. Nesse caso, a principal questão fiscal do governo central era garantir que os recursos para a educação primária e secundária fossem de fato aplicados pelos governos subnacionais de forma específica. Note-se que a educação primária e a secundária não são da competência funcional de um nível específico de governo. De acordo com a Constituição de 1988, a provisão de educação primária deveria ser atribuição dos municípios, com assistência técnica e financeira do governo federal e dos estados (Art. 30 da Constituição). A Emenda Constitucional no 14 contém artigos definindo as prioridades de cada nível de governo sem, porém, determinar uma clara especialização de competências. Entretanto, ela introduziu um sistema de incentivos que punia os municípios que não se especializassem na provisão de educação básica.

Em comparação com o setor de saúde, a vinculação de recursos para a área da educação começou bem mais cedo. A Constituição de 1988 continha dispositivos vinculantes mas mesmo antes de sua promulgação havia outros instrumentos com o mesmo propósito. Nos anos 1930, Vargas decretou que pelo menos $10 \%$ das receitas fossem gastos com educação. A Constituição de 1934 fixou tal percentual em 10\% e 20\% para os estados e municípios, respectivamente. A Constituição de 1946, por sua vez, continha dispositivos semelhantes (Sena, 2004: 3-4), os quais foram extintos durante o regime militar. Em 1983, porém, foi proposta uma emenda constitucional, a chamada emenda Calmon que estipulava níveis mínimos de gasto para a educação. A emenda Calmon destinava $13 \%$ das receitas tributárias líquidas para o governo 
federal (o que entrou em vigor apenas em 1985). A Constituição de 1988 aumentou para $18 \%$ o percentual do governo federal e estabeleceu que $25 \%$ das receitas tributárias líquidas iriam para os governos subnacionais. No caso do governo federal, o art. 60 das cláusulas transitórias da Constituição (ADCT) determinou que, por um período de 10 anos, $50 \%$ do montante equivalente a $18 \%$ das receitas seriam alocados em programas de alfabetização e na cobertura universal da educação básica. A proposta sofreu a resistência das burocracias do planejamento e fazendárias e de parlamentares que tinham ligações estreitas com esses círculos.

No final dos anos 1980 e início dos anos 1990, a centralidade da educação para o desenvolvimento tornou-se uma questão recorrente na agenda pública. Tanto no meio empresarial quanto nos movimentos sociais, emergiu um consenso para a elevação da qualidade da educação. O compromisso do governo de Fernando Henrique Cardoso com a reforma da educação refletiu-se na nomeação de um dos principais assessores econômicos para o cargo de ministro da Educação, em um novo padrão de recrutamento para cargos da maior importância, e na reforma importante da estrutura organizacional do setor ${ }^{8}$. O executivo estava empenhado no insulamento político do setor. O novo ministro da Educação era professor de economia e ex-reitor da Universidade de Campinas - de onde também se originou uma parte importante dos novos gestores do setor (uma parte importante dos quais esteve envolvido na criação do Bolsa Escola de Campinas). A principal questão de políticas era como melhorar a educação e promover a descentralização do setor ${ }^{9}$. Em muitas escolas da zona rural nordestina, a faixa salarial estava abaixo do salário-mínimo. Com recursos vinculados na Constituição, o desafio agora era garantir que os professores recebessem melhores salários. Em 1989, foi instalada uma Comissão Parlamentar de Inquérito - CPI para investigar a emenda Calmon. A comissão verificou que os estados gastavam em salários menos do que $20 \%$ das despesas constitucionalmente destinadas à educação. A conclusão geral foi que os salários extremamente baixos dos professores e a falta de treinamento estavam entre as principais razões da baixa qualidade da educação.

A mobilização nacional em torno da educação resultou finalmente na instituição do Fundef através da Emenda Constitucional no 14 e na aprovação da Lei de Diretrizes e Bases - LDB, a lei complementar que define as diretrizes básicas da educação, ambas de 1996. O projeto da LDB tinha sido aprovado na Câmara durante o governo Itamar Franco, 
mas a nova administração se opôs a muitos de seus dispositivos, particularmente na área de finanças públicas, por exigirem grande vinculação das finanças federais. Um projeto de lei completamente diferente foi então apresentado por um senador da oposição, Darcy Ribeiro (Partido Democrático Trabalhista - PDT-RJ), sendo finalmente aprovado. O Fundef exigia que, por um período de 10 anos, pelo menos $60 \%$ dos $25 \%$ dos recursos subnacionais destinados à educação fossem gastos no pagamento dos professores ativamente envolvidos em atividades de sala de aula ou em treinamentos de professores. Determinou também o estabelecimento de estruturas de carreira para os professores. Os recursos necessários para o aumento salarial e treinamento viriam de um fundo específico - ou fundos, melhor dizendo, porque, na verdade, cada estado tinha o seu próprio). A maior fonte de recursos do Fundo consistia em 15\% do Fundo de Participação dos Municípios FPM; 15\% da receita estadual do Imposto sobre Circulação de Mercadorias e Prestação de Serviços - ICMS; e uma contribuição suplementar do governo federal ${ }^{10}$. Esta última seria a quantia necessária para equalizar o gasto per capita em municípios cujos níveis de gasto estavam abaixo do gasto mínimo nacional per capita definido na lei orçamentária anual do país. Todas as transferências para o Fundef e os saques efetuados seriam automáticos e dependentes das transferências intergovernamentais definidas constitucionalmente.

A mais importante inovação consistia dos mecanismos que regiam a alocação dos recursos do fundo, os quais são distribuídos de acordo com o número de matrículas escolares em cada nível de governo. Isto produziu uma revolução na estrutura de incentivos da educação. Os prefeitos empenharam-se ativamente em atrair novos alunos porque receberiam mais transferências do fundo. Além disso, este encorajou a descentralização dos estados para os municípios, dado que haveria transferências negativas em alguns municípios se os serviços educacionais fossem prestados pelos estados. A nova estrutura de incentivos produziu dois resultados importantes: criou fortes incentivos para os governos municipais expandirem a cobertura nos seus territórios; e encorajou os municípios a assumirem os serviços educacionais prestados pelos estados. Os municípios onde a maior parte da educação básica era prestada pelos governos dos estados tinham que contribuir compulsoriamente com um mínimo de $25 \%$ de suas receitas para o Fundef, mas não poderiam receber recursos do fundo. Tal padrão prevaleceu em estados como São Paulo e Paraná. Em contrapartida, nos estados onde a educação básica já havia sido descentralizada para o âmbito 
municipal - como ocorreu no Rio de Janeiro, no Rio Grande do Sul e na maioria dos estados nordestinos - haveria uma redistribuição de recursos do estado para os municípios, especialmente para os municípios menores e periféricos.

Por ser o Executivo federal quem estabelecia o nível nacional de gastos per capita, ele possuía, em última análise, discricionariedade sobre o montante de recursos que canalizava para o Fundef. Em 1997, o nível per capita foi fixado em $\mathrm{R} \$ 300,00$. A Lei no 9429/96 exigia que, para 2001 (cinco anos depois), esse nível mínimo deveria levar em conta os recursos necessários para garantir um padrão básico de qualidade. A lei também determinava que o mínimo per capita para cada ano não deveria ser inferior à razão entre a receita esperada total do fundo no ano e o número de matrículas, conforme fornecido pelo censo educacional prévio, mais quaisquer acréscimos estimados ${ }^{11}$. Requeria também que as diferenças nos custos de prestação dos serviços de educação para todos os níveis escolares ( $1^{\mathrm{a}}$ a $4^{\mathrm{a}}$ séries; $5^{\mathrm{a}}$ a $8^{\mathrm{a}}$ séries; estudantes especiais etc.) fossem levadas em conta. O valor per capita de 1997 foi baseado apenas na receita projetada para aquele ano. Com o valor fixado em $\mathrm{R} \$$ 300,00 , o governo federal teve que liberar fundos de equalização para oito estados (de um total de 25) - todos no norte e no nordeste do país cujo gasto per capita era inferior àquele valor. No período de 1998-2002, o governo federal não fixou o padrão mínimo nacional de qualidade para a educação que a lei exigia. E, o que é mais importante, o gasto per capita não foi calculado com base na receita estimada do fundo. O nível inicial de $\mathrm{R} \$ 300,00$ permaneceu como o único parâmetro.

Tabela 1

Gasto Mínimo Per Capita com o Fundef

\begin{tabular}{|c|c|c|c|c|c|c|}
\hline \multirow[t]{2}{*}{ Ano } & \multicolumn{3}{|c|}{ Valor Mínimo (R\$) } & \multirow{2}{*}{$\begin{array}{c}\text { Crescimento } \\
\text { Anual }\end{array}$} & \multirow{2}{*}{$\begin{array}{l}\text { Taxa da } \\
\text { Inflação } \\
\text { (IPCA) }\end{array}$} & \multirow{2}{*}{$\begin{array}{c}\text { № de Estados que } \\
\text { Receberam Fundos } \\
\text { de Equalização }\end{array}$} \\
\hline & $\begin{array}{l}1^{\mathrm{a}} \text { a } 4^{\mathrm{a}} \\
\text { séries }\end{array}$ & $\begin{array}{l}5^{\underline{a}} \text { a } 8^{\text {a }} \\
\text { séries }\end{array}$ & $\begin{array}{l}1^{\mathrm{a}} \text { a } 8^{\mathrm{a}} \\
\text { séries }\end{array}$ & & & \\
\hline 1997 & & & 300,00 & - & - & \\
\hline 1998 & & & 315,00 & 5,0 & 1,65 & 7 \\
\hline 1999 & & & 315,00 & 0 & 8,94 & 8 \\
\hline 2000 & 333,00 & 349,65 & & 7,9 & 5,97 & 5 \\
\hline 2001 & 363,00 & 381,15 & & 9,0 & 7,67 & 4 \\
\hline 2002 & 418,00 & 438,90 & & 15,1 & 12,5 & 4 \\
\hline Acumulado & & & & 42,1 & 42,1 & \\
\hline
\end{tabular}

Fonte: Ministério da Educação (2003:4 e 8). 
Tabela 2

Fundos de Equalização do Governo Federal

\begin{tabular}{|c|c|c|c|c|}
\hline Ano & $\begin{array}{l}\text { Alocação Orçamentária } \\
\text { (em milhões de reais) (A) }\end{array}$ & $\begin{array}{l}\text { Executado } \\
\text { (B) }\end{array}$ & $\begin{array}{r}\% \\
\text { B/A }\end{array}$ & $\begin{array}{c}\% \mathrm{~B} / \text { total } \\
\text { Fundef }(\mathrm{C})\end{array}$ \\
\hline 1998 & - & 486,6 & - & 3,22 \\
\hline 1999 & 685,3 & 579,9 & 84,6 & 4,43 \\
\hline 2000 & 682,6 & 485,4 & 71,1 & 3,99 \\
\hline 2001 & 675,4 & 391,5 & 58,0 & 2,77 \\
\hline 2002 & 663,9 & 431,3 & 65,0 & 2,32 \\
\hline 2003 & 657,5 & 394,9 & 60,1 & - \\
\hline \multicolumn{3}{|l|}{ Média } & 67,8 & \\
\hline
\end{tabular}

Fonte: Ministério da Educação (2003:12), para (A) e (B); Costa (2004) para (C).

Um baixo gasto per capita gerou, na prática, um decréscimo nas transferências que o governo federal deveria fazer para o Fundef, no período de 1998 a 2003. Entre 1998 e 2002, o PIB nominal cresceu 46,0\%, a receita do Fundef subiu $76,5 \%$, e a quantidade de matrículas aumentou $5,3 \%$. Todavia, o valor mínimo per capita cresceu apenas $42,1 \%$ (veja a Tabela 1). Isso, combinado ao fato de as receitas do Fundef terem sido sistematicamente subestimadas, produziu um nível baixíssimo de execução das transferências federais orçadas (uma média de $67,8 \%$ para o período 1998-2003, conforme a Tabela 2). A parcela dos estados e municípios cresceu de forma semelhante. A lei que criou o Fundef era ambígua em relação a como o gasto per capita mínimo deveria ser calculado. O governo argumentou que, em razão de o Fundef ser um fundo de nível estadual, o valor per capita nacional deveria ser calculado como a média de todos os fundos estaduais (Ministério da Educação, 2003). Tal questão se tornou objeto de enorme controvérsia, envolvendo principalmente os partidos de oposição, as instituições representativas do setor educacional e a Procuradoria Geral da União. Se um mínimo nacional fosse calculado com base na receita total esperada das fontes vinculadas ao Fundef (dividido pelo número total de matrículas), o valor seria fixado em um nível muito alto e, em conseqüência, as contribuições do governo federal seriam mais elevadas. Sem dúvida, de acordo com estes últimos critérios, o nível nacional per capita seria estabelecido em $\mathrm{R} \$$ 418,70 (em vez de $\mathrm{R} \$ 315,00$ ), em 1998, e a parcela do governo federal subiria $423 \%$. O número de estados que se beneficiariam do programa subiria de sete para 17. Em todo o período 1998-2002, as contribuições do governo federal representaram apenas $15,6 \%$ do montante total es- 
timado, com o qual ele deveria ter contribuído no caso de o parâmetro mínimo nacional ser usado (idem:8).

Quem se opôs ao Fundef? Quem ganhou e quem perdeu com ele? Em termos de beneficiários diretos, estes foram, no curto prazo, os professores e municípios nos quais os salários eram baixos. Houve também redistribuição, dos municípios urbanos para os rurais dentro de um mesmo estado. O impacto do Fundef também dependeu fundamentalmente da relação entre o total de matrículas nas escolas estaduais e municipais em cada estado. Como visto anteriormente, os estados com as quantidades mais altas de matrículas no curto prazo beneficiar-se-iam mais. Em contrapartida, onde o percentual de matrícula fosse pequeno, quem ganharia seriam os municípios. Os estados mais pobres também ganhariam, já que estariam qualificados a receber transferências equalizadoras do governo federal. Observe-se que os professores seriam os maiores beneficiários, independentemente de tal relação, por causa do gasto mínimo obrigatório de $60 \%$ em salários ou treinamentos de professores ${ }^{12}$. Por essa razão, os sindicatos de professores deram certo apoio ao Fundef. Contudo, os movimentos de esquerda e partidos opuseram-se ao programa do governo de Fernando Henrique Cardoso. O maior dos sindicatos, a Confederação Nacional dos Trabalhadores em Educação - CNTE, fazia parte da Central Única dos Trabalhadores - CUT.

ACNTE, uma confederação de sindicatos de âmbito estadual, cujos empregadores eram os estados e municípios, estava fragmentada no nível nacional (em contraste com suas congêneres na maioria dos países latino-americanos, onde os docentes tinham como empregadores os governos federais). O aumento de salário dos professores era uma das bandeiras da CNTE, a qual fazia pressão para a criação de um piso salarial nacional. De fato, a CNTE, juntamente com a União Nacional dos Dirigentes Municipais de Educação - UNDIME e o Conselho Nacional dos Secretários Estaduais de Educação - CONSED, conseguiu chegar a um acordo nesse sentido com o governo Itamar Franco, durante a Primeira Conferência Nacional da Educação. No acordo, assinado em 1994, foi fixado um piso salarial mínimo para os professores de $R \$$ 300,00. Todavia, por razões de ordem política e técnica, o governo foi contra a proposta (Maria Helena Castro, em entrevista com o autor). Primeiro, acreditava-se que o programa daria origem à criação de um movimento sindical muito mais forte no setor da educação, o qual era dominado pelo Partido dos Trabalhadores - PT. Nas palavras de Cas- 
tro: "quando os professores entrarem em greve no Acre, os de São Paulo seguirão o exemplo. Seria a federalização das greves"13. Embora muitos assessores importantes do governo - inclusive a Primeira Dama, professora Ruth Cardoso, que liderava o Comunidade Solidária - a tivessem apoiado, a proposta não foi aprovada (Gilda Portugal, em entrevista com o autor, 2003). Segundo, muitos assessores argumentavam que a proposta não era consistente com a estrutura federativa brasileira. Os municípios apresentavam grandes diferenças econômicas, fiscais e de custo de vida. Terceiro, muitos municípios pagavam os professores com base em uma quantidade específica de horas-aula, o que tornava impossível a adoção do piso nacional. As outras partes envolvidas na discussão representavam os interesses do setor público. Os atores principais na discussão da iniciativa eram duas instituições: a UNDIME e o CONSED. Apesar de manterem vínculos (embora mais fracos) com os partidos de oposição, elas apareciam como entidades não-partidárias. A entidade mais ativa era a UNDIME, que compartilhava muitos interesses com a CNTE (CNTE, 1999; UNDIME, 1999) ${ }^{14}$.

Apesar de louvar a iniciativa, a UNDIME argumentou que o Fundef era um mecanismo de "redistribuição dos recursos já disponíveis no nível estadual" e que, ao fixar o valor per capita em um nível tão baixo, o governo federal conseguiu gastar menos recursos na educação primária (UNDIME, 1999). Durante a aprovação do Fundef, o presidente vetou três dispositivos, atraindo subseqüentemente várias críticas da UNDIME e da CNTE. Eram dispositivos que permitiam a inclusão de jovens e adultos no programa; proibiam o governo federal de usar sua quota no imposto cobrado dos empregadores para a educação (o Salário Educação) nas transferências de equalização para o Fundef; e que exigiam a transferência automática das quotas estaduais para os municípios, em vez do Fundef. Os vetos tiveram por objetivo garantir que o governo federal reduzisse suas contribuições para o fundo e mantivesse controle sobre o Fundef e sobre o comportamento dos municípios. É interessante notar que tais associações terminaram por não desempenhar o papel de críticos ou de opositores do Fundef, mas de seus mais fortes apoiadores. Isso ocorreu por ter se convertido em críticos da alegada falta de aplicação ou de implementação das suas disposições.

Em termos do que prediz a literatura sobre as reformas de segunda geração, esse resultado é um paradoxo. Em vez de se opor à iniciativa de reforma, as forças de oposição pressionaram para uma implementação mais efetiva das reformas. É significativo que o PT tenha votado contra 
o Fundef nos dois turnos de votação na Câmara, mas tenha sido favorável na votação do Senado. Uma oposição mais explícita à reforma ocorreu no caso dos governadores dos estados no qual a descentralização já havia sido substancial. Durante as negociações da emenda e da Lei no 9424, os governadores dos estados que eram "perdedores potenciais" pressionaram por um período de transição de cinco anos, ao invés dos três meses propostos, e por um esquema de compensação. O que ocorreu foi a extensão do período de transição por um ano, além de um programa de modernização e ampliação das escolas secundárias. Esse programa foi a "moeda política" para a aprovação do Plano Avança Brasil (Maria Helena Castro, em entrevista com o autor).

A tramitação legislativa da proposta do Fundef durou quase um ano. Um passo crucial deu-se quando uma disposição sobre a autonomia das universidades, que estava bloqueando as negociações, foi removida. Em suma, o mecanismo do Fundef foi uma iniciativa altamente bem-sucedida do governo de Fernando Henrique Cardoso, que produziu uma intensificação da descentralização da educação no Brasil. Contribuiu também para a melhoria das condições de trabalho e dos salários dos professores, particularmente no nordeste, onde subiram em média 70\%, entre 1997 e 2000 (dados supridos pelo INEP). A proporção de professores leigos nos sistemas municipais caiu de $12 \%$ dos professores em 1997 para 5\% em 2000. O aumento na cobertura exigiu também a contratação de mais professores. No período de 1997 a 2000, o número de professores municipais cresceu de 600.000 para aproximadamente 750.000 (World Bank, 2002). Ao mesmo tempo, o peso dos diferentes níveis de governo foi alterado, com os governos municipais agora representando quase $38 \%$ dos gastos, em comparação com $27 \%$ dos gastos em 1995. Os municípios, como um todo, gastaram quase R $\$$ 24 bilhões em educação no ano 2000, quase o dobro do que gastaram, em termos reais, em 1995 (idem).

Muitas mudanças foram realizadas a um baixo custo para o Executivo, o qual conseguiu revolucionar a estrutura de incentivos dos prefeitos e governadores na área educacional. Tal iniciativa refletiu a preocupação da sociedade e das elites burocráticas do governo com a educação e, ao mesmo tempo, contribuiu para garantir a manutenção do controle federal sobre o processo. Foi também consistente com a preocupação do governo federal com as questões fiscais. Os constrangimentos fiscais levaram o governo a não aumentar o nível per capita, apenas a ajustá-lo à taxa da inflação. De fato, o governo reduziu a parcela dos fundos de 
equalização na receita total ao longo do tempo. A lógica das iniciativas do governo federal foi semelhante às que envolveram o sistema de saúde pública: tentativas de controlar e assegurar o gasto subnacional, em um contexto de rápida descentralização e, conseqüentemente, de alta incerteza em relação aos resultados. A unificação dos recursos em uma única conta foi essencial para assegurar o controle federal do gasto subnacional. De forma consistente com suas preferências de expansão fiscal no âmbito local, os governos subnacionais têm pressionado o governo federal a aumentar o nível per capita nacional. Entretanto, as necessidades fiscais têm levado o governo a não o reajustar. $\mathrm{O}$ governo federal quer controlar tanto as prioridades quanto os gastos subnacionais, ao mesmo tempo em que mantém suas próprias metas fiscais como a principal variável de ajuste.

O caso do Fundef ilustra como o desenho da reforma pode contribuir para a superação da resistência às reformas. Assume-se normalmente que as reformas da segunda geração produzem apenas "perdedores" e poucos, ou não tão claros, "vencedores". Os benefícios da reforma são geralmente considerados bens públicos. No caso do Fundef, ficou claro que ela beneficiou um setor específico - os professores e os municípios pequenos. Os sindicatos dos professores e os interesses do setor educacional acabaram sendo, portanto, não pontos de veto, mas atores pró-reforma. Embora muitos desses interesses fossem ideologicamente opostos ao governo de Fernando Henrique Cardoso, eles não foram capazes de se opor à proposta de reforma como tal. Uma explicação alternativa para esse fenômeno, com base na literatura discutida na seção inicial deste artigo, é que, no caso do Fundef, a "política de eficiência/qualidade" se confundiu com a "política da expansão". Buscou-se a qualidade e a eficiência de forma indireta, pela melhoria dos salários, e não pela imposição de metas de qualidade. A interpretação alternativa neste caso é que a reforma a criação do Fundef não constituiria um caso típico ou puro de reforma de segunda geração. Neste caso a tipologia de reformas necessitaria de ser reformulada.

O caso do Fundef mostra também que uma classe importante de perdedores - os governadores estaduais - não conseguiu impedir as reformas. Eles foram parcialmente compensados pelo governo federal. $\mathrm{O}$ Executivo conseguiu superar a resistência ao reconstruir o federalismo brasileiro em favor do Centro. Além disso, o caso do Fundef ilustra como o governo federal conseguiu pôr em prática a reforma em um contexto de austeridade fiscal. O aumento das alíquotas e o aperfeiçoa- 
mento da arrecadação dos impostos ligados ao Fundef causaram o declínio gradual dos fundos de equalização do governo federal, porém mais recursos foram canalizados para a educação primária.

\section{CONCLUSÕES}

Neste artigo, argumento que a transformação no padrão da política social foi possível como resultado de uma combinação de fatores. Primeiro, o Executivo no Brasil têm a capacidade institucional de implementar sua agenda. Em que pesem os constrangimentos da política de coalizão, eles possuem a capacidade de aprovar reformas no Congresso. Os presidentes são poderosos institucionalmente e têm a capacidade de restringir o comportamento fiscal subnacional. Como assinalado, a ampla reestruturação das relações intergovernamentais mostrou-se fundamental para a transformação do padrão de políticas sociais no país. Segundo, os presidentes também têm incentivos para tomar medidas fiscalmente responsáveis e, ao mesmo tempo, implementar reformas sociais. Os presidentes são punidos ou premiados pelo seu desempenho no combate à inflação e em assegurar baixos níveis de desemprego. Nos anos 1990, o eleitorado tornou-se avesso à inflação e, ao mesmo tempo, emergiu um consenso na opinião pública, nas elites empresariais e entre os parlamentares em torno da redução da pobreza. $\mathrm{O}$ produto final desse consenso foi o jogo constitucional em torno da vinculação de recursos para as áreas sociais da saúde e da redução da pobreza em geral. As emendas constitucionais representaram compromissos críveis no sentido de que os recursos seriam alocados nas áreas sociais. O Congresso aceitou a instituição de novos impostos ou alíquotas para os impostos existentes em troca de mais recursos fiscais, inclusive para os setores sociais que passaram a absorver uma parcela cada vez mais expressiva do orçamento. O Executivo foi capaz de conciliar as demandas de sua coalizão de apoio com o insulamento da política social da competição política mais ampla. Isso implicou na reorganização do lugar dos ministérios sociais no jogo da política de coalizão. Ademais, o Executivo conseguiu reduzir as "perdas de agência" associadas à descentralização, fazendo uso de uma estratégia dupla: criando uma estrutura de incentivos que permitiu o alinhamento dos interesses do governo federal e das unidades subnacionais, particularmente dos governos municipais (vide Fundef) e estipulando regras fiscais severas para governos subnacionais. Tal estratégia foi apenas parcialmente bem-sucedida porque os prefeitos e outros atores locais ain- 
da podiam controlar um mecanismo importante: o registro de beneficiários dos programas de transferências sociais.

A literatura sobre a segunda geração de reformas de fato tende a exagerar os mecanismos de resistência à reforma. Uma série de fatores contribuiu para que essa resistência fosse superada. A estratégia big bang do governo de Fernando Henrique Cardoso mostrou-se efetiva no estabelecimento de um vínculo entre o programa altamente popular de controle da inflação e o restante de sua agenda. Segundo, houve amplo consenso nacional sobre a necessidade de combate à pobreza. Esta, quando extrema, era vista não apenas como abjeta, mas também como prejudicial à competitividade do país. Isso contribuiu para formar um consenso e criar apoio para a redução da pobreza. No entender de Nelson (2000), o consenso aumentou os custos políticos de não fazer a reforma. Na verdade, tal consenso se manifestou na competição política em torno da paternidade do Fundo de Combate à Pobreza (e particularmente do Bolsa Escola). Terceiro, a inexistência de modelos de reforma na área social pareceu ser uma vantagem, ao invés de um problema. A transferência de políticas normalmente gera problemas de implementação pela dificuldade de adaptação a modelos exógenos. No caso brasileiro, o conhecimento especializado de políticas nas áreas sociais foi essencial para o processo de inovação doméstica. De fato, o Fundef (como também o Bolsa Escola) foram programas desenhados nos principais ministérios sociais, e não importados. A resistência dos provedores de serviços - professores, sindicatos e empregados do setor de saúde - foi muito menor do que o esperado, devido à estrutura de incentivos criada para a descentralização.

No texto também destaquei dois aspectos negligenciados na literatura. Primeiro, a política de formação de ministérios no país sofreu uma ruptura em torno de seu conteúdo substantivo setorial. Segundo, que o amplo processo de reforma constitucional esteve ancorado na reforma do federalismo brasileiro. As implicações dessa transformação para o funcionamento do sistema político e para as políticas públicas em geral são seguramente uma importante tarefa para o futuro.

(Recebido para publicação em janeiro de 2005)

(Versão definitiva em agosto de 2005) 


\section{NOTAS}

1. Cf entre as exceções Draibe (2004) e Almeida (2004). Em geral, a literatura tende a apenas privilegiar um aspecto do conteúdo programático da política social - a expansão e predominância de programas universais - ignorando-se as mudanças ocorridas.

2. Em 2002, o Bolsa Escola envolveu gastos da ordem de US $\$ 800$ milhões. A cobertura e capilaridade do programa também foram significativas: o programa beneficiou 11 milhões de crianças e cerca de 5 milhões de famílias; uma em cada três crianças do país, com idades entre 7 e 14 anos, recebeu a bolsa em 2002.

3. A rigor a transformação centrou-se nas relações intergovernamentais e não no federalismo enquanto desenho constitucional. A fronteira entre os dois aspectos, como se notará ao longo da análise, é freqüentemente tênue. Agradeço à Celina Souza por chamar a atenção para este ponto.

4. A literatura sobre a economia política das reformas chama a atenção para problemas de inconsistência temporal em reformas seqüenciadas que podem levar ao malogro, mas destacam também que as reformas tipo big bang podem se tornar inviáveis se um componente essencial do pacote de reformas falhar, contaminando por extensão os outros componentes.

5. Categorizamos as emendas da seguinte forma (cinco categorias foram utilizadas): as questões relacionadas aos setores econômicos (tais como telecomunicações, monopólios públicos etc.) foram classificadas como "econômicas"; as questões pertinentes a instituições políticas, regras de decisão, cidadania etc. foram classificadas como "institucionais"; as questões de "controle fiscal" referem-se a todas as emendas com o objetivo específico de controle de gastos e de disciplina fiscal; as emendas que têm implicações relevantes para as relações intergovernamentais são classificadas como "federalismo"; "políticas e direitos sociais" são auto-explicativos. Estas categorias não são mutuamente exclusivas, dentre outras coisas porque muitas emendas são longas peças legislativas "multidimensionais", mas ajudam a destacar a importância do federalismo. Sobre a hiperconstitucionalização no Brasil cf Melo (2006).

6. Cf Corrales (2003) para a discussão do fenômeno em outros países.

7. O mecanismo descrito acima foi gerado durante a descentralização da saúde pública. O ponto de partida foi, como discutido anteriormente neste artigo, a Lei Orgânica da Saúde (1990), que regulamentou as provisões constitucionais voltadas para a descentralização. A descentralização foi significativa: os municípios foram responsáveis por 9,6\% do gasto total em saúde pública em 1985 (Arretche, 2003:331-332). Esse percentual subiu para 35\% em 1996 e atingiu $43 \%$ em 2000. A mudança, em termos de fonte de recursos para a saúde pública, foi igualmente significativa. O percentual subiu de 9,3\% em 1985 para $28 \%$ em 1996. Por sua vez, a parcela do governo federal declinou de $73 \%$ para $53 \%$ no mesmo período. Em 2000, os municípios eram responsáveis por $89 \%$ dos procedimentos básicos de saúde - tal percentual era 65\% em 1995.

8. Deve-se notar que, ao contrário de países como Argentina e México, a educação primária no Brasil já era razoavelmente descentralizada. Historicamente, o governo federal não tem tido papel algum na educação básica. Seria mais apropriado descrever o processo como uma intensificação da descentralização, em um arranjo institucional já descentralizado. 


\section{Marcus André Melo}

9. Outras fontes menos importantes incluíam: 15\% do Imposto sobre Produtos Industrializados - IPI, fixados como proporção das exportações dos estados e $15 \%$ das perdas estaduais oriundas da exclusão do ICMS sobre as exportações. Ver Castro (1998).

10. No começo do ano, o governo federal fixaria o montante de recursos devido a cada município, o que era estabelecido como um percentual da receita esperada do Fundo e calculado com base na matrícula dos alunos.

11. Os aumentos nos recursos municipais ocorreram principalmente com a redistribuição de recursos dos estados para os municípios. O mecanismo do Fundef gera redistribuição apenas dentro de um mesmo estado, e não de um estado rico para os menos abastados. Os governos estaduais do nordeste e o Rio de Janeiro são responsáveis por grande parte das transferências redistributivas. Um número relativamente pequeno de estados é responsável por um grande volume na redistribuição de recursos, embora haja uma certa redistribuição dos municípios ricos para os pobres. Só o governo estadual do Rio de Janeiro representa quase um quarto das transferências de estados para municípios, enquanto os nove estados do nordeste constituem metade da redistribuição do Fundef (World Bank , 2002). O Fundef também promove distorções entre os diversos níveis da educação básica (infantil, fundamental e médio). Cf Ulyssea, Fernandes e Gremaud, 2005.

12. Ver também Souza (2002) a respeito da "federalização das greves".

13. A UNDIME foi criada em 1986, durante o processo de transição para a democracia, logo se tornando um fórum de articulação de demandas no setor educacional na Assembléia Constituinte e para a discussão da Nova Lei de Diretrizes da Educação, de 1996. Deve-se notar que muitas das demandas da UNDIME foram incorporadas na proposta do Fundef, inclusive a proposta para "municipalizar" a educação fundamental e buscar mais recursos para o pagamento e treinamento dos professores. A ex-presidente da UNDIME, no período 1994-1995 - Maria Helena Castro - foi indicada para diversos cargos no Ministério da Educação, como secretária do Ministério da Educação e presidente do Instituto Nacional de Estudos e Pesquisas Educacionais Anísio Teixeira - INEP (o think tank do MEC). A CNTE e a UNDIME criticaram fortemente o nível fixado para o mínimo per capita. Chegaram a acionar judicialmente o governo, alegando descumprimento da Constituição - por não ter implementado a emenda constitucional que ele mesmo propôs. Além disso, criticavam a retenção de recursos como o FEF e o DRU pelo governo federal. A CNTE e a UNDIME pressionaram pela inclusão de adultos analfabetos e alunos deficientes no Fundef.

14. Ver também Souza (2004:89-91). 


\section{REFERÊNCIAS BIBLIOGRÁFICAS}

ABRUCIO, Fernando (1998). Os Barões da Federação - Os Governos e a Redemocratização Brasileira. São Paulo, Hucitec.

ALSTON, Lee, MELO, Marcus, MUELLER, B. e PEREIRA, C. (2004), Political Institutions, Policy-Making Processes and Policy Outcomes in Brazil. Relatório de Pesquisa, Washington, Inter-American Development Bank..

. (2005), “Who Decides on Public Expenditures: The Political Economy of the Budgetary Process: The case of Brazil, Washington". Economic and Social Studies Series RE 05-006, Inter-American Development Bank.

ALMEIDA, Maria H. T. de. (2004), "A Política Social do Governo Lula”. Novos Estudos Cebrap, $\mathrm{n}^{\mathrm{o}}$ 70, pp. 7-18.

AMES, Barry. (2001), The Deadlock of Democracy in Brazil. Ann Arbor, University of Michigan Press.

AMORIM NETO, Octavio. (2002), "Presidential Cabinets, Electoral Cycles, and Coalition Discipline in Brazil", in S. Morgenstern e B. Nacif (eds.), Legislative Politics in Latin America. New York, Cambridge University Press.

ARRETCHE, Marta. (2003), “Financiamento Federal e Gestão Local de Políticas Sociais: O Difícil Equilíbrio entre Regulação, Responsabilidade e Autonomia". Ciência e Saúde Coletiva, vol. 8, nº 2, pp. 331-345.

BURKI, Shahid Javed, PERRY, Guillermo E. e DILLINGER, William R. (1999), Beyond the Center: Decentralizing the State. Washington, DC, The World Bank.

CASTRO, Jorge Abrahão. (1998), O Fundo de Manutenção e Desenvolvimento do Ensino e Valorização do Magistério (Fundef) e seu Impacto no Financiamento do Ensino Fundamental. Texto para Discussão, nํㅡ 604. Brasília, Instituto de Pesquisa Econômica Aplicada.

CNTE - Confederação Nacional dos Trabalhadores em Educação. (1999), Plano Nacional de Educação, Seminário sobre o FUNDEF: Apreciação da CNTE. Brasília. Manuscrito.

CONGRESSO NACIONAL. (1999), Comissão Mista Especial Destinada a Estudar as Causas Estruturais e Conjunturais das Desigualdades Sociais e Apresentar Soluções Legislativas para Erradicar a Pobreza e Marginalização e Reduzir as Desigualdades Sociais e Regionais. Relatório Final, 99 pp.

CORRALES, Javier. (2003), The Conflict between Technocracy and Participation in Education Reforms in Latin America. Trabalho apresentado no XXIV Congresso International da LASA, Dallas, Texas.

COSTA, Bruno L. (2004), Desigualdade Educacional e Coordenação Intergovernamental: OCaso do FUNDEF (Fundo de Desenvolvimento do Ensino Fundamental e Valorização do Magistério) em Minas Gerais. Trabalho apresentado no Congresso do Clad, Madrid, novembro.

DILLINGER, William e WEBB, Steven. (1999), "Fiscal Management in Federal Democracies: Argentina and Brazil". Policy Research Paper, 2121. Washington, DC, World Bank. 
DRAIBE, Sônia. (2002), Brasil, 1980-2000: Proteção e Insegurança Sociais em Tempos Difíceis. Trabalho apresentado no seminário Inter-Regional Protección Social en una Era Insegura: Un Intercambio Sur-Sur sobre Políticas Sociales Alternativas en Respuesta a la Globalización. Santiago, Chile, 14-16 de maio.

. (2004), “Federal Leverage in a Decentralized System: Education Reform in Brazil", in R. Kauffman e J. Nelson (eds.), Crucial Needs, Weak Incentives: Social Sector Reform, Democratization and Globalization in Latin America. Baltimore, The Johns Hopkins University Press, pp.375-406.

FARIA, Vilmar. (2002), “Reformas Institucionales y Coordinación Gubernamental en la Política de Protección Social de Brasil". Revista de la CEPAL, no 77, agosto, pp. 7-24.

FIGUEIREDO, Argelina e LIMONGI, F. (1999). Executivo e Legislativo na Nova Ordem Constitucional. São Paulo, Fundação Getulio Vargas Editora.

GOLDFAJN, Ilan e GUARDIA, Eduardo R. (2003), “Fiscal Rules and Debt Sustainability in Brazil". Banco Central do Brasil Technical Notes, no 39.

GRAHAM, Carol e NAÍN, Moisés. (1999), “The Political Economy of Institutional Reform", in N. Birdsall, C. G. Graham e R. Sabot (eds.), Beyond Trade Offs: Market Reforms and Equitable Growth. Washington, DC, Brookings Institution/IDB.

GRINDLE, Merilee. (2000), “The Social Agenda and the Politics of Reform in Latin America", in J. Tulchin e A. Garland (eds.), Social Development in Latin America. London/Boulder, Lynne Rienner.

. (2001), "Despete of government the Odds: The Political Economy of Social Sector Reforms in Latin America". Research Working Papers Series, RWP01-021, Cambridge, MA. Havard University, Kennedy School of Government.

. (2004), Despite the Odds: The Contentious Politics of Educational Reform. Princeton, Princeton University Press.

HAGGARD, Stephan e WEBB, Steve. (2004), “Political Incentives and Intergovernmental Fiscal Relations: Argentina, Brazil and Mexico Compared", in A. P. Montero e D. J. Samuels (eds.), Decentralization and Democracy in Latin America. Notre Dame, University of Notre Dame Press.

KAUFFMAN, Robert R. e NELSON, J. (eds.). (2004a), Crucial Needs, Weak Incentives: Social Sector Reform, Democratization and Globalization in Latin America. Baltimore, The Johns Hopkins University Press, pp.375-406.

. (2004b), "The Politics of Education Sector Reform: Cross National Comparisons", in R. Kauffman e J. Nelson (eds.), Crucial Needs, Weak Incentives: Social Sector Reform, Democratization and Globalization in Latin America. Baltimore, The Johns Hopkins University Press, pp. 249-281.

LOUREIRO, Maria Rita e ABRUCIO, Fernando. (1999), “Política e Burocracia no Presidencialismo Brasileiro: O Papel do Ministério da Fazenda no Primeiro Governo Fernando Henrique Cardoso". Revista Brasileira de Ciências Sociais, vol. 14, no 41, pp. 69-89.

MAINWARING, Scott. (1999), Rethinking Party Systems in the Third Wave of Democratization: The Case of Brazil. Stanford, Stanford University Press. 
eSHUGART, Matthew. (1997), Presidentialism and Democracy in Latin America. Cambridge, Cambridge University Press.

MACEIRA, Daniel e MURILLO, M. Victoria. (1999), “Social Sector Reform in Latin America and the Role of Unions". Working Paper, 456, Inter-American Development Bank, Research Department.

MELO, Marcus André. (2002). Reformas Constitucionais no Brasil. Instituições Políticas e Processo Decisório. Rio de Janeiro, Revan.

. (2003), “When Institutions Matters: The Politics of Administrative, Social Security and Tax Reform in Brazil", in B. R. Schneider e B. Heredia (orgs.), Reinventing Leviathan: The Political Economy of Administrative Reform in Developing Countries. Miami, FL, University of Miami, North-South Center Press.

. (2004), "Escolha Institucional e a Difusão dos Paradigmas de Política: O Brasil e a Segunda Onda de Reformas Previdenciárias". Dados, vol. 47, noำ1, pp. 169-206.

(2006), Federalism, Hyperconstitutionalization and Constitutional Reforms in Brazil. Trabalho preparado para o Congresso Internacional da International Political Science Association, Fukuoka, pp. 9-13.

MINISTÉRIO DA EDUCAÇÃO. (2003), Relatório do Grupo de Trabalho sobre o Valor Mínimo do FUNDEF. Brasília, Documento Interno.

NAÍN, Moisés. (1995), “Latin America's Journey to the Market: From Macroeconomic Shocks to Institutional Therapy". OCEG Occasional Paper, 끈 62. San Francisco, International Center for Economic Growth.

NAVIA, Patricio e VELASCO, Andres. (2003), “The Politics of Second-Generation Reforms", in P. P. Kuczynski e J. Williamson, After the Washington Consensus: Restarting Growth and Reform in Latin America. Washington, DC, The Institute of International Economics.

NELSON, Joan. (2000), "Reforming Social Sector Governance: A Political Perspective", in J. Tulchin e A. Garland (eds.), Social Development in Latin America. London/Boulder, Lynne Rienner.

. (2004), "The Politics of Health Sector Reform: Cross National Comparisons", in R. Kauffman e J. Nelson (eds.), Crucial Needs, Weak Incentives: Social Sector Reform, Democratization and Globalization in Latin America. Baltimore, The Johns Hopkins University Press, pp. 23-63.

e TOMMASI, Mariano. (2002), Politicians, Public Support and Social Equity Reforms. Trabalho apresentado no III Encontro do Social Equity Forum do Inter-American Development Bank, Santiago.

PASTOR, Manuel e WISE, Carol. (1999), “The Politics of Second-Generation Reform”. Journal of Democracy, vol.10, no 3, pp. 34-48.

PEREIRA, Carlos e MUELLER, Bernardo. (2003), “The Cost of Governing: Strategic Behavior in Brazil's Budgetary Process". Comparative Political Studies, vol. 37, no 7, pp. 781-815.

RODDEN, Jonathan. (2003), "Federalism and Bailouts in Brazil", in J. Rodden, G. Eskeland eJ. Litvack (eds.), Fiscal Decentralization and the Challenge of Hard Budget Constraints. Cambridge, The MIT Press. 


\section{Marcus André Melo}

RODRIK, Dani. (2004), Getting the Institutions Right. Harvard University, disponível em http://ksghome.harvard.edu/ drodrik/papers.html.

SAMUELS, David. (2003), Ambition, Federalism and Legislative Politics in Brazil. New York, Cambridge University Press.

SCHNEIDER, Aaron. (2004), Wholesale versus Within Institution Change: Pacting Governance Reform in Brazil for Fiscal Responsibility and Tax. University of Sussex Institute of Development Studies. Manuscrito.

SCHNEIDER, Ben Ross e HEREDIA, Blanca. (2003), Reinventing Leviathan: the politics of Administrative Reform in Developing Countries. Miami, North Center Press/University of Miami.

SENA, Paulo de. (2004), A União e a Vinculação dos Recursos Aplicados à Manutenção de Desenvolvimento do Ensino. Brasília, Câmara dos Deputados, Consultoria Legislativa. Manuscrito.

SOUZA, Celina. (2003), “Federalismo e Conflitos Distributivos: Disputa dos Estados por Recursos Orçamentários Federais". Dados, vol. 46, nº 2, pp. 345-384.

SOUZA, Paulo Renato de. (2004), A Revolução Gerenciada: Educação no Brasil 1995-2002. São Paulo, Pierson-Prentice Hall.

TREISMAN, Daniel (2004) "Stabilization Tactics in Latin America: Menem, Cardoso, and the Politics of Low Inflation". Comparative Politics, vol. 36, no 4, pp.399-420.

TULCHIN, Joseph e GARLAND, Allyson (eds.). (2000), Social Development in Latin America. London/Boulder, Lynne Rienner.

ULYSSEA, Gabriel, FERNANDES, Reynaldo e GREMAUD, Amaury. (2005), Alocação de Recursos para a Educação Básica o Impacto do FUNDEF. IPEA, documento interno.

UNDIME. (1999), O Fundef na Avaliação da UndimE. Brasília. Manuscrito.

WORLD BANK. (2002), Brazil Municipal Education Resources, Incentives, and Results. Relatório no 24413-BR, Washington, DC, 2 vols. 


\begin{abstract}
The Unexpected Success of Second Generation Reforms: Federalism, Constitutional Reforms and Social Policy

The paper argues that unlike the predictions of the literature on second-generation reforms, there occurred an important change in the pattern of social policy during the Cardoso years, with the attendant improvement in social indicators. The budgetary process has been increasingly and extensively hardwired; inter-governmental relations have undergone extensive restructuring; and the line ministries in the social area have been insulated from coalition-building politics. It argued that the change was determined by the broader transformation of Brazilian federalism caused by an extensive process of constitutional reform, and that the executive had both the incentives and the capabilities to promote it.
\end{abstract}

Key words: second-generation reforms; social policy; federalism

\title{
RÉSUMÉ
}

Le Succès Inattendu des Réformes de Deuxième Génération: Fédéralisme, Réformes Constitutionnelles et Politique Sociale

Dans cet article, on affirme qu'il y a eu un changement dans le modèle de la politique sociale brésilienne pendant le gouvernement Fernando Henrique Cardoso, ce que la littérature sur les réformes de deuxième génération n'avait pas prévu. Selon le nouveau modèle, les mécanismes budgétaires se sont avérés de plus en plus liés au domaine social: les relations inter-gouvernementales ont subi un changement considérable et le rôle des ministères à caractère social dans la politique de formation des cabinets présidentiels a été redéfini. Ce changement est devenu possible grâce aux transformations significatives qui se sont produites dans le fédéralisme brésilien à la suite d'un long processus de changement constitutionnel. Dans ce texte, on montre que le pouvoir exécutif a disposé de capacités institutionnelles et a été poussé à mettre en place le changement.

Mots-clé: réformes de deuxième génération; politique sociale; fédéralisme 